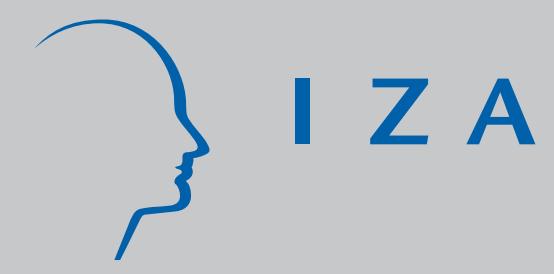

IZA DP No. 1900

Big Fish in Small Pond or Small Fish in Big Pond? An Analysis of J ob Mobility

Ana Rute Cardoso

December 2005 


\title{
Big Fish in Small Pond or Small Fish in Big Pond? An Analysis of Job Mobility
}

\author{
Ana Rute Cardoso \\ IZA Bonn, \\ University of Minho and CEPR \\ Discussion Paper No. 1900 \\ December 2005
}

\author{
IZA \\ P.O. Box 7240 \\ 53072 Bonn \\ Germany \\ Phone: +49-228-3894-0 \\ Fax: +49-228-3894-180 \\ Email: iza@iza.org
}

\begin{abstract}
Any opinions expressed here are those of the author(s) and not those of the institute. Research disseminated by IZA may include views on policy, but the institute itself takes no institutional policy positions.

The Institute for the Study of Labor (IZA) in Bonn is a local and virtual international research center and a place of communication between science, politics and business. IZA is an independent nonprofit company supported by Deutsche Post World Net. The center is associated with the University of Bonn and offers a stimulating research environment through its research networks, research support, and visitors and doctoral programs. IZA engages in (i) original and internationally competitive research in all fields of labor economics, (ii) development of policy concepts, and (iii) dissemination of research results and concepts to the interested public.
\end{abstract}

IZA Discussion Papers often represent preliminary work and are circulated to encourage discussion. Citation of such a paper should account for its provisional character. A revised version may be available directly from the author. 
IZA Discussion Paper No. 1900

December 2005

\section{ABSTRACT}

\section{Big Fish in Small Pond or Small Fish in Big Pond? An Analysis of Job Mobility}

The statement that individuals care for status and for their position within a hierarchy has been subject to sparse economic analysis. I check this assertion by analyzing wages and status within the firm, with status measured as the worker rank in the firm wage hierarchy. More precisely, I focus on worker mobility between jobs, to compare movers and stayers in terms of gains/losses in wage level versus gains/losses in rank position. The following questions are addressed: Upon switching firm, what do workers gain/loose in terms of wage and in terms of rank position? Is there a trade-off between wage and rank? If so, does it vary across groups of workers? A remarkable longitudinal linked employer-employee dataset is used. Estimation takes account of worker unobserved heterogeneity. Results indicate that movers are subject to slower rank progression than stayers. That penalty is larger the larger the new firm when compared to the old one. Moreover, faster rank progression is achieved by movers at the price of slower wage progression, suggesting the existence of a trade-off between wage and status.

JEL Classification: J63, J31, J41

Keywords: linked employer-employee data, job mobility, wage structure, wage ranks

Corresponding author:

Ana Rute Cardoso

IZA

Schaumburg-Lippe-Str. 7/9

53113 Bonn

Germany

Email: cardoso@iza.org

\footnotetext{
* I am grateful to Dan Hamermesh and the participants in seminars held at National University of Ireland Maynooth and IZA Bonn for their comments. I relied extensively on valuable suggestions by Peter Mueser to improve on an earlier version of the paper. The collaboration of the Statistics Department, Ministry of Employment, Portugal, providing access to the data used, is acknowledged.
} 


\section{Introduction}

Individuals care for status and for their position within a hierarchy - this statement has been subject to sparse economic analysis, in contrast to the psychology and sociology literatures. Hamermesh (1975) introduced interdependencies among workers when modeling labor demand and labor supply, as individual effort and productivity would depend, not just on the worker's own wage, but also on a comparison wage, for example the average wage in the firm. Frank (1984) underlined the existence of, not just one comparison point, but multiple reference points, as workers care about their ordinal position in a hierarchy, i.e. their status. According to his model, workers search for status and are willing to pay for improved status in the form of a lower wage (relative to their marginal productivity); conversely, a lower status within a firm would be compensated with a higher wage (relative to the worker's marginal productivity), since otherwise the worker would have an incentive to join a firm where the productivities and wages of co-workers would be closer to his own. This trade-off between wage and status would be the key to explain the observed compression of the distribution of wages within firms, when compared to the distribution of productivities. The idea that workers will pay for status in the form of a lower wage is also discussed in Weiss and Fershtman (1998), who model its impact on wage differentials, output, and welfare. Moldovanu et al (2005) insightful model focuses on the optimal definition of status categories by a principal wanting to maximize performance in an organization made up of agents who care about relative positions. For other models of interdependencies among individuals' preferences and interactions between money and status in a framework extending beyond the labor market, see for instance van de Stadt et al (1985), Robson (1992), Layard (1980), Frank (1985), or, more recently, Becker et al (2005), Hopkins and Kornienko (2004) or the overview in Frank (2005) (an illustration of a different strand of literature, analyzing interactions shaped by reciprocity and fairness considerations, is Fehr and Schmidt 2001).

On the empirical front, the issue has been handled by looking at the impact of pay rank on job and wage satisfaction. Comparisons in the labor market, in particular on wages, have been shown to influence job satisfaction and to have 
an impact on worker productivity, through absentism, shirking, and turnover (see the early paper by Hamermesh 1977, or Clark and Oswald 1996, Bygren 2004, Taylor and Vest 1992, Groot and van den Brink 1999, and Ward and Sloane 2000). Recently, Brown et al (2005) have used laboratory experiments complemented with survey data to show that workers care, not just about their absolute pay level, but also about their pay relative to the mean of their group and, moreover, about the rank they occupy in the pay distribution. On the other hand, Charness and Kuhn (2004) have challenged the idea that firms adopt a compressed wage distribution because workers care about co-workers wages and adjust their level of effort accordingly. Evidence from their laboratory experiment indicates instead that workers' effort depends only on own wage and not on co-workers' wages. Neumark and Postlewaite (1998) present an interesting application to female labor force participation, showing that concern over relative incomes may draw women into the labor force.

I will focus on worker mobility between jobs, looking at the associated gains or losses in wage level versus gains or losses in rank position, thus setting the analysis of the topic in a different framework. The aim is to test whether job movers are willing to trade wage gains for improvements in hierarchical position. The following questions will be addressed: Is there a trade-off between wage and status? Upon switching firm, what do workers gain or loose in terms of wage and of rank position? Does willingness to pay for status vary across individuals? Since a high rank in a large firm is likely to have attached a higher status than a similar rank in a small firm, the impact of the size of the firm will deserve particular attention. This paper therefore follows literature on job mobility, in particular that focusing on wage changes following a move between firms of different sizes. Examples of this literature include Winter-Ebmer and Zweimüller (1999), Abbott and Beach (1994) and Brown and Medoff (1989). The analysis of changes in rank position is novel.

The study is based on a remarkable longitudinal linked employer-employee dataset covering each year approximately two million workers in manufacturing and services private sector in Portugal. The population of wage-earners in those sectors and their firms are covered, thus reducing problems commonly faced by 
panel datasets, such as panel attrition and over- or under-sampling of certain groups. Moreover, the legal requirement for the data to be posted in a public space in the firm contributes to its reliability, reducing measurement errors. Having a panel on both workers and their firms covering the population of those units opens wide possibilities for the analysis of worker mobility across firms.

Section 2 presents the data set and discusses the concepts used. Section 3 describes the methodology and presents the results, and section 4 checks the robustness of the results. Concluding comments are presented in section 5 .

\section{Data set and discussion of concepts}

Response to an annual inquiry (Quadros de Pessoal) by the Ministry of Employment is mandatory to every firm employing wage-earners in the private sector in Portugal. Reported data include the firm's location, industry, employment, sales, ownership, legal setting, and the worker's gender, age, occupation, schooling, tenure, earnings, duration of work, date of latest promotion, and collective bargaining agreement. The administrative nature of the dataset and the legal obligation for the data to be posted in a public space in the company contribute to its reliability. Data from 1991 to 2000 are used.

The study focuses on full-time wage-earners aged 18 to 65 , whose wage is not below the national minimum wage. ${ }^{1}$ Workers observed in two consecutive periods, either remaining in the same firm or switching firms, have been kept for analysis. Given the aim of looking at wage ranks within the firm, a minimum firm size threshold had to be imposed. As such, only workers observed in firms with at least 10 workers will be analyzed and robustness checks will be implemented. The final dataset under analysis includes over 6 million observations on 1.7 million workers. Descriptive statistics and further information on the construction of the dataset are presented in appendix.

Gross hourly wages were computed as $h w=\frac{b w+s e n+r e g}{n o r m h}$, where $b w$ stands for monthly base-wage, sen are seniority-indexed components of pay, reg are other regularly paid benefits, and normh refers to the normal duration of work expressed in hours. Wages were deflated using the Consumer Price Index (base 2000). Wage

\footnotetext{
${ }^{1}$ May drop apprentices and handicapped workers.
} 
outliers $^{2}$ and outliers in wage growth ${ }^{3}$ have been dropped.

Each worker was assigned his/her wage rank within the firm, which was then standardized to fall in the interval from 1 (lowest position in the firm) to 100 (highest position in the firm). The measure can thus be interpreted as the worker's percentile rank in the wage distribution:

$$
\text { relative } \operatorname{rank}_{i j}=\left(\frac{R_{i j}}{N_{j}}\right) * 100,
$$

where $i$ refers to the worker, $j$ to the firm, $N_{j}$ is total employment in firm $j$, and $R_{i j}$ ranges between 1 and $N_{j}, 1$ being the lowest paid and $N_{j}$ the highest paid worker in the firm. All the workforce of the firm was taken into consideration when computing the relative rank, thus including workers who joined the firm in the current period and those that will leave it in the next period.

The idea that status depends on income finds wide support in the literature. For example, Becker et al (2005) consider both the possibility of existence of a market for status and the possibility that it depends only on rank in the distribution of income. The model of conspicuous consumption by Hopkins and Kornienko (2004) illustrates the relevance of wealth for the definition of status. For a discussion of the relevance of wages for the definition of occupational status, see Fershtman and Weiss (1993).

The idea that individuals value their rank position has been even more extensively documented (for a recent overview, see Frank (2005); for a distinction between types of "positional goods", see Solnick and Hemenway (2005)).

The choice of comparison group has deserved particular attention (for example by Patchen 1961, Bygren 2004, Goodman 1974, Oldham et al 1986, Dornstein 1988, Taylor and Vest 1992, or Law and Wong 1998). Most evidence supports the idea that comparisons in the labor market are most relevant, and that individuals care in particular for reference groups they are closer to or a part of, such as coworkers, namely because they have more information on those groups. Bygren (2004) however finds that Swedish workers adopt more general groups for their comparisons, such as their occupation or the overall labor market, which could be due to the high unionization level in the country and the centralized nature of

\footnotetext{
${ }^{2}$ Wages above 20 times the percentile 99 .

${ }^{3}$ Ratio of wages in two consecutive years smaller than $1 / 6$ or larger than 6 .
} 
wage-setting. Either way, the synthesis of this literature seems to be that ranks matter and that individuals usually compare themselves to those who are similar to them, their peers. In Frank's words, "it is local rank that matters most" (Frank, 2005: 138).

Faced with the choice of the reference group, two alternatives could be implemented. The first would be to adopt a very narrow definition based on the firm, broad occupation, education, and age. However, since each group would have to have a minimum size to yield a relevant definition of the rank, a too large share of the dataset would have to be disregarded. The second alternative would be to take the rank within the firm, and to model changes in the rank controlling for age, education, and broad occupation. This alternative will be implemented.

\section{Job switchers: the trade-off between wage and rank}

This section performs a comparative analysis of changes in (log) wage and changes in rank position between workers who moved and those who stayed in the same firm. Gains or losses in rank may have attached different relevance depending on the size of the firms involved, since a high rank in a large firm is likely to be more valued than a similar rank in a small firm. The crucial variables of interest are therefore whether the worker has switched firm and the change in the relative size of the ponds, i.e. the previous and current firms.

The focus of attention are short-run gains from job mobility, defined as the difference in outcomes between workers who switched firms in a given period and similar workers who did not. A crucial aspect in the empirical model is that movers are likely to be different from stayers in unobservable ways (they can differ in their capacity to take initiatives and degree of risk aversion, motivation, etc). Also, dismissed workers may differ from those voluntarily quitting a job. Even though the database does not include information on whether the move was initiated by the worker or the employer, it does enable identification of firm closures. Moves from firm closing down are involuntary moves and will be accounted for in the regressions. ${ }^{4}$ Also, the panel nature of the dataset enables accounting for time-

\footnotetext{
${ }^{4}$ Note however that workers who remain long-term unemployed following closure of their firm will not be captured in the dataset the following year and are thus out of the scope of this analysis.
} 
invariant worker unobserved heterogeneity.

The first approach will thus be to estimate the following equations:

$$
Y_{i t}=\alpha_{1} \text { mov }_{i t}+\alpha_{2} \operatorname{clos}_{i t}+\alpha_{3} \text { Dsize }_{i t}+\alpha_{4} \text { Dsize }_{i t} * m o v+\beta^{\prime} x_{i t}+\mu_{i}+\varepsilon_{i t},
$$

where $Y$ stands for the change in (log) real wage or the change in rank between periods $t-1$ and $t$, mov is a dummy variable equal to 1 if the worker switched firms between $t-1$ and $t$, clos is an indicator of involuntary job move, equal to one for workers displaced in period $t-1$ due to firm closure, and Dsize is the $(\log )$ difference between the size of the firm in periods $t-1$ and $t$; the vector $x$ includes a quadratic term on age and a quadratic term on tenure (years working for the firm ${ }^{5}$ ), and controls for broad occupation (one dummy for white-collars), industry (16 dummies), location (one dummy for Lisbon), origin of the firm capital (dummies for foreign and public capital), year, to capture economy-wide wage fluctuations, and education of the worker (dummies for high school and university diploma); $\mu_{i}$ is a control for worker-specific time-invariant unobservables, and $\varepsilon_{i t}$ is a stochastic error. Given that the same set of regressors is included in both equations, estimation of a seemingly unrelated regression model that would allow for correlation in the error terms across equations for the same worker yields the same results as separate OLS estimation of the two equations.

Results for the overall working population are presented in table 1. University graduates and white-collars enjoy faster wage progression. Wage growth tends to decrease with age, consistent with the usual concavity of the age-earnings profile. The same profile holds for progression along the ranks of the firm, with university educated workers and white-collars progressing faster. Movers in general enjoy faster wage growth than stayers the year the move takes place. However, as expected, that wage growth is reduced if the move follows displacement due to firm closure. Expanding firms yield slightly lower wage growth, but provide opportunity for incumbent workers to climb up the ranks. Movers switching to a larger firm enjoy larger wage growth, consistent with the established result that larger firms pay higher wages.

Results on rank progression for the movers contrast with those on wage progression. Indeed, movers undergo a decline in rank position, when compared to

\footnotetext{
${ }^{5}$ Referring to the previous period.
} 


\begin{tabular}{lcc}
\hline & wage & rank \\
\cline { 2 - 3 } & $(1)$ & $(2)$ \\
\hline high school & .0004 & $-.208^{*}$ \\
& $(.001)$ & $(.117)$ \\
university & $.015^{* * *}$ & $1.262^{* * *}$ \\
& $(.002)$ & $(.215)$ \\
age & $-.003^{* * *}$ & $-.361^{* * *}$ \\
& $(.0005)$ & $(.043)$ \\
age sq. / 100 & $.004^{* * *}$ & $.491^{* * *}$ \\
& $(.0002)$ & $(.018)$ \\
tenure (previous job) & $-.001^{* * *}$ & $-.186^{* * *}$ \\
& $(.00007)$ & $(.006)$ \\
tenure sq. / 100 & $.006^{* * *}$ & $.433^{* * *}$ \\
& $(.0002)$ & $(.021)$ \\
white collar & $.004^{* * *}$ & $.381^{* * *}$ \\
& $(.0005)$ & $(.043)$ \\
mover & $.055^{* * *}$ & $-1.679^{* * *}$ \\
& $(.0006)$ & $(.051)$ \\
firm closure & $-.043^{* * *}$ & $-.571^{* * *}$ \\
& $(.001)$ & $(.129)$ \\
change in firm size $(\log )$ & $-.002^{* * *}$ & $3.819^{* * *}$ \\
mover $*$ change firm size & $(.0004)$ & $(.037)$ \\
Const. & $.027^{* * *}$ & $-5.829^{* * *}$ \\
Obs. & $(.0005)$ & $(.044)$ \\
$\sigma_{\varepsilon}$ & $.154^{* * *}$ & $9.41^{* * *}$ \\
$\rho$ & $(.015)$ & $(1.379)$ \\
& $6,435,333$ & $6,435,333$ \\
& 0.12 & 11.57 \\
& 0.18 & 16.50 \\
& 0.32 & 0.33 \\
\hline
\end{tabular}

Table 1: Change in (LOG) WAGE AND ChAnge IN RANK, WORKER FIXed EFfeCts.

Note: Includes controls for year, industry (16 dummies), location (1 dummy), and the origin of the capital of the firm (2 dummies). Source: Computations based on Portugal, MTSS (1991-2000). 
their peers who stay in the same firm. That penalty in terms of rank progression is larger the larger the new firm compared to the old one. A trade-off between moving for a better wage but lower status seems to emerge from these results.

Tables 6 to 8 in appendix split the results by gender and schooling group, showing a consistent pattern. In particular, movers enjoy faster wage progression than stayers, at the price of slower rank progression. That trade-off is reinforced the larger the size of the new firm relative to the old one. The only exception are male university graduates, for whom both wage and rank tend to improve upon switching firms.

The evidence so far gathered on the existence of a trade-off between wage change and change in relative rank is valid for movers as a group. A more direct test on whether, at the individual level, those workers who move to higher pay loose in terms of relative rank, is called for. One way to tackle the issue directly is to include the wage change in the regression predicting change in relative rank. Table 2 reports the results, comparing the previous specification (column 1) with the new specification (column 2). Results are striking.

Movers enjoy slower rank progression than workers who stay in the same firm. That penalty is larger the larger the new pond when compared to the old one. Moreover, the faster the wage growth of movers when compared to stayers, the larger the price paid in terms of rank progression. Quantifying this trade-off, the coefficient -19.3 in this level-log regression means that, when compared to stayers, if the wage of a mover increases $10 \%$ faster, (s)he looses 2 percentage points in relative rank progression; stated conversely, larger increases in relative rank for movers seem to be paid for with slower wage growth. This set of results thus highlights the existence of a trade-off between progression in wage and in ranks for individual workers switching firms.

\section{Robustness checks}

Several considerations could undermine the reliability of the previous result on workers' willingness to trade-off wage for status. First of all, the relative rank measure may not be truly comparable across firms with different numbers of employees. For example, in a firm with ten workers, the lowest paid worker will have 


\begin{tabular}{|c|c|c|}
\hline & rank & rank \\
\hline independent variable & $(1)$ & $(2)$ \\
\hline high school & $\begin{array}{c}-.208^{*} \\
(.117)\end{array}$ & $\begin{array}{c}-.233^{* *} \\
(.099)\end{array}$ \\
\hline university & $\begin{array}{c}1.262^{* * *} \\
(.215)\end{array}$ & $\begin{array}{c}.665^{* * *} \\
(.183)\end{array}$ \\
\hline age & $\begin{array}{c}-.361^{* * *} \\
(.043)\end{array}$ & $\begin{array}{c}-.189^{* * *} \\
(.036)\end{array}$ \\
\hline age sq. / 100 & $\begin{array}{c}.491^{* * *} \\
(.018)\end{array}$ & $\begin{array}{c}.311^{* * *} \\
(.016)\end{array}$ \\
\hline tenure (previous job) & $\begin{array}{c}-.186^{* * *} \\
(.006)\end{array}$ & $\begin{array}{c}-.076^{* * *} \\
(.005)\end{array}$ \\
\hline tenure sq. / 100 & $\begin{array}{c}.433^{* * *} \\
(.021)\end{array}$ & $\begin{array}{c}.133^{* * *} \\
(.017)\end{array}$ \\
\hline white collar & $\begin{array}{c}.381^{* * *} \\
(.043)\end{array}$ & $\begin{array}{l}.21^{* * *} \\
(.037)\end{array}$ \\
\hline mover & $\begin{array}{c}-1.679^{* * *} \\
(.051)\end{array}$ & $\begin{array}{c}-2.408^{* * *} \\
(.045)\end{array}$ \\
\hline firm closure & $\begin{array}{c}-.571^{* * *} \\
(.129)\end{array}$ & $\begin{array}{c}.623^{* * *} \\
(.11)\end{array}$ \\
\hline change in firm size (log) & $\begin{array}{c}3.819^{* * *} \\
(.037)\end{array}$ & $\begin{array}{c}3.965^{* * *} \\
\quad(.031)\end{array}$ \\
\hline mover $*$ change firm size & $\begin{array}{c}-5.829^{* * *} \\
(.044)\end{array}$ & $\begin{array}{c}-6.698^{* * *} \\
(.038)\end{array}$ \\
\hline change real wage (log) & & $\begin{array}{c}50.485^{* * *} \\
\quad(.039)\end{array}$ \\
\hline mover ${ }^{*}$ wage change & & $\begin{array}{c}-19.318^{* * *} \\
(.119)\end{array}$ \\
\hline Const. & $\begin{array}{c}9.41^{* * *} \\
(1.379)\end{array}$ & $\begin{array}{l}2.02^{*} \\
(1.173)\end{array}$ \\
\hline Obs. & $6,435,333$ & $6,435,333$ \\
\hline$\sigma_{\mu}$ & 11.57 & 9.89 \\
\hline$\sigma_{\varepsilon}$ & 16.50 & 14.01 \\
\hline$\rho$ & 0.33 & 0.33 \\
\hline
\end{tabular}

Table 2: ChAnge IN RANK, WORKER FIXED EFFECTS.

Note: Includes controls for year, industry (16 dummies), location (1 dummy), and the origin of the capital of the firm (2 dummies). Source: Computations based on Portugal, MTSS (1991-2000).

relative rank equal to 10 (see equation 1 ), as his/her position covers the percentiles 1 to 10 . In a firm with a hundred workers, the corresponding value will be 1 , and therefore comparison of the ranks in those two firms might not be insightful. I check whether results still hold once the firm size threshold is raised to one hundred workers, thus providing more comparable information on ranks across firms. Table 3, columns 1 and 2, show that indeed all the results still hold: movers have slower rank progression, which is reinforced the larger the new firm with respect to the old firm, and faster rank growth can be paid for with slower wage growth. 
That table introduces further robustness checks. One second aspect to take into account is that the overall wage distribution is skewed, denser in the middle, with a long upper tail. As such, a comparable change in wage is likely to lead to larger changes in rank for workers in the middle or bottom of the distribution than at the top. Therefore, in columns 3 and 4 the initial wage is added to the independent variables. Results show that in general, the higher the initial wage, the slower the rank progression. Column 4 further highlights that a jump in intermediate ranks is cheaper than a jump at the top; in other words, if subject to the same change in wage, workers at the top of the wage distribution progress less gain less in the rank than workers further down. Climbing up at the top ranks is more expensive than further down in the wage distribution, which could be due to the skewness of the distribution. The patterns previously detected still hold, once that characteristic of the distribution is accounted for.

Column 5 further considers the interaction between initial wage and wage change, specifically for movers. Interestingly, movers from the top of the wage distribution loose less in terms of status. Though the overall pattern still holds, workers with higher initial wages are less subject to losses in rank position.

Tables 9 to 16 in appendix present the results separately for males and females and by education group. In synthesis, a consistent pattern emerges, with movers from one firm to another subject to a penalty relative to stayers in terms of status improvement. This slower rank progression is reinforced the larger the difference in the size of the old and new firms. The trade-off between wage growth and rank progression also holds. The notable exception occurs with males holding a university diploma. In general, upon moving firms, these workers do not loose status within the firm (see the insignificant coefficient on the mover variable in table 13, column 5). These workers seem to enjoy better job offers, associated with both wage increases and moves up the ranking. However, they do loose status when changing to a larger firm. Also, sharper gains in status are achieved at the cost of lower wage growth. 


\begin{tabular}{|c|c|c|c|c|c|}
\hline independent variable & $(1)$ & $(2)$ & $(3)$ & $(4)$ & $(5)$ \\
\hline high school & $\begin{array}{l}.171 \\
(.161)\end{array}$ & $\begin{array}{c}-.29^{* *} \\
(.131)\end{array}$ & $\begin{array}{c}.255^{* *} \\
(.131)\end{array}$ & $\begin{array}{l}-.147 \\
(.127)\end{array}$ & $\begin{array}{l}-.157 \\
(.127)\end{array}$ \\
\hline university & $\begin{array}{c}1.658^{* * *} \\
(.265)\end{array}$ & $\begin{array}{c}.842^{* * *} \\
(.215)\end{array}$ & $\begin{array}{c}.969^{* * *} \\
(.215)\end{array}$ & $\begin{array}{c}1.344^{* * *} \\
(.209)\end{array}$ & $\begin{array}{c}1.268^{* * *} \\
(.209)\end{array}$ \\
\hline age & $\begin{array}{c}-.36^{* * *} \\
(.055)\end{array}$ & $\begin{array}{c}-.208^{* * *} \\
(.044)\end{array}$ & $\begin{array}{c}-.193^{* * *} \\
(.044)\end{array}$ & $\begin{array}{r}-.033 \\
(.043)\end{array}$ & $\begin{array}{l}-.04 \\
(.043)\end{array}$ \\
\hline age sq. / 100 & $\begin{array}{c}.432^{* * *} \\
(.027)\end{array}$ & $\begin{array}{c}.273^{* * *} \\
(.022)\end{array}$ & $\begin{array}{c}.255^{* * *} \\
(.022)\end{array}$ & $\begin{array}{c}.068^{* * *} \\
(.021)\end{array}$ & $\begin{array}{c}.076^{* * *} \\
(.021)\end{array}$ \\
\hline tenure (previous job) & $\begin{array}{c}-.158^{* * *} \\
(.01)\end{array}$ & $\begin{array}{c}-.065^{* * *} \\
(.008)\end{array}$ & $\begin{array}{c}-.062^{* * *} \\
(.008)\end{array}$ & $\begin{array}{l}-.008 \\
(.008)\end{array}$ & $\begin{array}{l}-.011 \\
(.008)\end{array}$ \\
\hline tenure sq. / 100 & $\begin{array}{c}.462^{* * *} \\
(.027)\end{array}$ & $\begin{array}{c}.062^{* * *} \\
(.022)\end{array}$ & $\begin{array}{c}.051^{* *} \\
(.022)\end{array}$ & $\begin{array}{c}-.084^{* * *} \\
(.021)\end{array}$ & $\begin{array}{c}-.083^{* * *} \\
(.021)\end{array}$ \\
\hline white collar & $\begin{array}{c}.36^{* * *} \\
(.054)\end{array}$ & $\begin{array}{l}.056 \\
(.044)\end{array}$ & $\begin{array}{l}.083^{*} \\
(.044)\end{array}$ & $\begin{array}{l}.037 \\
(.042)\end{array}$ & $\begin{array}{l}.046 \\
(.042)\end{array}$ \\
\hline mover & $\begin{array}{c}-2.046^{* * *} \\
(.099)\end{array}$ & $\begin{array}{c}-3.463^{* * *} \\
(.085)\end{array}$ & $\begin{array}{c}-3.484^{* * *} \\
(.085)\end{array}$ & $\begin{array}{c}-4.064^{* * *} \\
(.082)\end{array}$ & $\begin{array}{c}-24.552^{\text {*** }} \\
(.793)\end{array}$ \\
\hline firm closure & $\begin{array}{c}1.122^{* * *} \\
(.27)\end{array}$ & $\begin{array}{c}2.422^{* * *} \\
(.219)\end{array}$ & $\begin{array}{c}2.45^{* * *} \\
(.219)\end{array}$ & $\begin{array}{c}2.8^{* * *} \\
(.213)\end{array}$ & $\begin{array}{c}2.284^{* * *} \\
(.213)\end{array}$ \\
\hline change in firm size (log) & $\begin{array}{c}4.285^{* * *} \\
(.054)\end{array}$ & $\begin{array}{c}5.031^{* * *} \\
(.043)\end{array}$ & $\begin{array}{c}5.035^{* * *} \\
(.043)\end{array}$ & $\begin{array}{c}5.129^{* * *} \\
(.042)\end{array}$ & $\begin{array}{c}5.121^{* * *} \\
(.042)\end{array}$ \\
\hline mover ${ }^{*}$ change firm size & $\begin{array}{c}-6.361^{* * *} \\
(.081)\end{array}$ & $\begin{array}{c}-7.547^{* * *} \\
\quad(.066)\end{array}$ & $\begin{array}{c}-7.555^{* * *} \\
(.066)\end{array}$ & $\begin{array}{c}-8.027^{* * *} \\
(.064)\end{array}$ & $\begin{array}{c}-7.675^{* * *} \\
(.064)\end{array}$ \\
\hline change real wage (log) & & $\begin{array}{c}52.763^{* * *} \\
(.047)\end{array}$ & $\begin{array}{c}52.352^{* * *} \\
(.059)\end{array}$ & $\begin{array}{c}228.221^{* * *} \\
(.447)\end{array}$ & $\begin{array}{c}232.312^{* * *} \\
(.456)\end{array}$ \\
\hline mover $*$ wage change & & $\begin{array}{c}-17.917^{* * *} \\
(.227)\end{array}$ & $\begin{array}{c}-17.948^{* * *} \\
(.227)\end{array}$ & $\begin{array}{c}-22.48^{* * *} \\
(.22)\end{array}$ & $\begin{array}{c}-105.825^{* * *} \\
(2.229)\end{array}$ \\
\hline init. wage & & & $\begin{array}{c}-.807^{* * *} \\
(.07)\end{array}$ & $\begin{array}{c}-1.905^{* * *} \\
(.068)\end{array}$ & $\begin{array}{c}-2.04^{* * *} \\
(.068)\end{array}$ \\
\hline init. wage ${ }^{*} \mathrm{w}$ change & & & & $\begin{array}{c}-25.287^{* * *} \\
(.064)\end{array}$ & $\begin{array}{c}-25.882^{* * *} \\
(.065)\end{array}$ \\
\hline mover $*$ init. wage & & & & & $\begin{array}{c}3.14^{* * *} \\
(.117)\end{array}$ \\
\hline mover $*$ init. $\mathrm{w}^{*} \mathrm{w}$ change & & & & & $\begin{array}{c}12.337^{* * *} \\
(.324)\end{array}$ \\
\hline Const. & $\begin{array}{c}9.226^{* * *} \\
(1.807)\end{array}$ & $\begin{array}{l}2.315 \\
(1.465)\end{array}$ & $\begin{array}{c}7.321^{* * *} \\
(1.528)\end{array}$ & $\begin{array}{c}10.311^{* * *} \\
(1.482)\end{array}$ & $\begin{array}{c}11.346^{* * *} \\
(1.481)\end{array}$ \\
\hline Obs. & $3,380,351$ & $3,380,351$ & $3,380,351$ & $3,380,351$ & $3,380,351$ \\
\hline$\sigma_{\mu}$ & 10.59 & 8.54 & 8.53 & 8.37 & 8.37 \\
\hline$\sigma_{\varepsilon}$ & 15.10 & 12.25 & 12.25 & 11.88 & 11.87 \\
\hline$\rho$ & 0.33 & 0.33 & 0.33 & 0.33 & 0.33 \\
\hline
\end{tabular}

Table 3: ChANGE IN RANK, WORKER FIXED EFFECTS, FIRMS LARGER THAN 100 WORKERS. Note: Includes controls for year, industry (16 dummies), location (1 dummy), and the origin of the capital of the firm (2 dummies). Source: Computations based on Portugal, MTSS (1991-2000).

\section{Conclusion}

This study analyzed worker mobility between firms, to compare gains or losses in wage level versus gains or losses in rank position of movers and stayers. Results indicate that movers in general are subject to slower rank progression than stayers, 
more so the larger the difference in the size of the old and new firms. Moreover, faster rank progression is achieved by movers at the price of slower wage progression, suggesting the existence for movers of a trade-off between wage and status.

Relying on the richness of the data used, which enables tracking all workers moving firms in the private sector of the economy, the results provide an alternative view on the idea that workers care about their relative position in a hierarchy, with the reward package including both money and status.

\section{References}

Abbott, Michael G. And Charles M. Beach (1994). Wage changes and job changes of Canadian women: evidence from the 1986-87 labour market activity survey. Journal of Human Resources, 29(2): 429-460.

Becker, Gary S., Kevin M. Murphy, and Iván Werning (2005). The equilibrium distribution of income and the market for status. Journal of Political Economy, 113(2): 282-310.

Brown, Charles and James Medoff (1989). The employer size-wage effect. Journal of Political Economy, 97(5): 1027-1059.

Brown, Gordon D. A., Jonathan Gardner, Andrew Oswald, And JING QIAN (2005). Does wage rank affect employees' wellbeing? IZA discussion paper 1505. Bonn: Institute for the Study of Labor.

Bygren, Magnus (2004). Pay reference standards and pay satisfaction: what do workers evaluate their pay against? Social Science Research, 33: 206-224.

Charness, Gary And Peter Kuhn (2004). Do co-workers' wages matter? Theory and evidence on wage secrecy, wage compression and effort. Mimeo, University of California, Santa Barbara.

Clark, Andrew E. And Andrew J. Oswald (1996). Satisfaction and comparison income. Journal of Public Economics, 61: 359-381.

Dornstein, Miriam (1988). Wage reference groups and their determinants: a study of blue-collar and white-collar employees in Israel. Journal of Occupational Psychology, 61: 221-235. 
Fehr, ERnst And Klaus Schmidt (2001). Theories of fairness and reciprocity - evidence and economic implications. CEPR discussion paper 2703. London: Centre for Economic Policy Research.

Fershtman, Chaim and Yoram Weiss (1993). Social status, culture and economic performance. Economic Journal, 103(419): 946-959.

Frank, Robert H. (1984). Are workers paid their marginal products? American Economic Review, 74(4): 549-571.

FrAnk, RoberT H. (1985). Choosing the right pond: human behaviour and the quest for status. Oxford: Oxford University Press.

Frank, Robert H. (2005). Positional externalities cause large and preventable welfare losses. American Economic Review, 95(2): 137-141.

Goodman, Paul S. (1974). An examination of referents used in the evaluation of pay. Organizational Behavior and Human Performance, 12: 170-195.

Groot, Wim and Henriette MaAssen van den Brink (1999). Overpayment and earnings satisfaction: an application of an ordered response Tobit Model. Applied Economics Letters, 6: 235-238.

Hamermesh, Daniel S. (1975). Interdependence in the labor market. Economica, 42(168): 420-429.

Hamermesh, Daniel S. (1977). "Economic aspects of job satisfaction." In Orley Ashenfelter and Wallace Oates (eds.) Essays in Labor Market and Population Analysis. New York: Wiley, p. 53-72.

Hopkins, Ed and Tatiana Kornienko (2004). Running to keep in the same place: consumer choice as a game of status. American Economic Review, 94(4): 1085-1107.

Law, Kenneth S. And Chi-Sum Wong (1998). Relative importance of referents on pay satisfaction: a review and test of a new policy-capturing approach. Journal of Occupational and Organizational Psychology, 71: 47-60. 
LAYARD, R. (1980). Human satisfactions and public policy. Economic Journal, 90(360): $737-750$.

Moldovanu, Benny, Aner Sela, and Xianwen Shi (2005). Contests for status. Mimeo, University of Bonn.

Neumark, David and Andrew Postlewaite. (1998). Relative income concerns and the rise in married women's employment. Journal of Public Economics, 70: 157-183.

Oldham, Greg R., Carol T. Kulik, Lee P. Stepina, and Maureen L. Ambrose (1986). Relations between situational factors and the comparative referents used by employees. Academy of Management Journal, 29(3): 599608.

Patchen, Martin (1961). The choice of wage comparisons. New Jersey: Prentice-Hall.

Portugal, Ministério do Trabalho e da Segurança Social (1991 to 2000). Quadros de Pessoal. Data in magnetic media.

Robson, Arthur J. (1992). Status, the distribution of wealth, private and social attitudes to risk. Econometrica, 60(4): 837-857.

Solnick, Sara J. And David Hemenway (2005). Are positional concerns stronger in some domains than in others? American Economic Review, 95(2): 147-151.

Taylor, G. Stephen and Michael J. Vest (1992). Pay comparisons and pay satisfaction among public sector employees. Public Personnel Management, 21(4): 445-454.

van de Stadt, Huib, Arie Kapteyn, and Sara van de Geer (1985). The relativity of utility: evidence from panel data. Review of Economics and Statistics, 67(2): 179-187.

Ward, Melanie E. And Peter J. Sloane (2000). Non-pecuniary advantages versus pecuniary disadvantages; job satisfaction among male and female aca- 
demics in Scottish universities. Scottish Journal of Political Economy, 47(3): 273-303.

Weiss, Yoram and Chaim Fershtman (1998). Social status and economic performance: a survey. European Economic Review, 42: 801-820.

Winter-Ebmer, Rudolf And Josef Zweimüller (1999). Firm-size wage differentials in Switzerland: evidence from job-changers. American Economic Review, 89(2): 89-93.

\section{Appendix: Longitudinal linked employer-employee data set}

The data are gathered annually in an inquiry to employers, who must report information on all the personnel working for the firm in a reference week (whether wage-earners, firm owners working for the firm, or unpaid family members). Public administration and domestic service are not covered, and the coverage of agriculture is low, given its low share of wage-earners. For the remaining sectors, the mandatory nature of the survey leads to an extremely high response rate.

A worker identification code, based on a transformation of the social security number, enables tracking him/her over time. Similarly, a firm identification code enables tracking the employer. The Ministry checks that a firm is not assigned a new number if it has previously reported to the database. These checks are based mainly on its location and legal identification codes. On the worker side, extensive checks have been performed to guarantee the accuracy of the data, using gender, date of birth, highest schooling level achieved, and date of hiring. In particular, inconsistencies were identified if the worker gender or date of birth was reported changing, or if the highest schooling level achieved was reported decreasing over time. In such cases, the information reported over half the times has been taken as the correct one ${ }^{6}$ (thus correcting $0.8 \%, 2.3 \%$, and $5.2 \%$ of the observations, respectively for gender, birth date, and education). Workers with inconsistent data after the introduction of the previous corrections were dropped $(1.7 \%, 1.1 \%$, and $4.3 \%$ of the observations respectively). Workers with missing data after the introduction of the previous corrections were dropped $(0.7 \%$ and

\footnotetext{
${ }^{6}$ Note that this requirement is more demanding than just considering the modal value as the accurate one.
} 
$1.7 \%$ of the observations, due to missing date of birth or schooling, respectively, corresponding to $2.1 \%$ and $2 \%$ of the workers).

Further checks concerned the date of hiring of the worker. In particular, inconsistencies were identified if the reported date of hiring was later than the date the worker was first observed working for that firm, or if different dates of hiring were reported for the same employment spell. If different valid dates of hire remained within an employment spell, the first one reported was considered the accurate one (correcting $0.7 \%$ of the observations).

Worker mobility across firms was coded into: stayer (61\%); mover (4\%); fake mover, a worker who apparently switched firm but whose date of hire is the same as in the previous employment spell (which may happen once the legal entity of the firm changes, but the actual unit of employment remains unchanged, such as with some mergers or takeovers, apparent firm bankruptcies, or when the worker is placed in another firm belonging to the same group) (1.5\%); unsure move, whenever the worker apparently switched firm, but (s)he is reported hired more than a year ago $(0.4 \%) .^{7}$ The checked panel included approximately 19 million observations worker-year on 4 million workers.

The analysis focuses on wage-earners working full-time, aged 18 to 65, whose wage is not below the national minimum wage (which led to dropping successively $20 \%, 2 \%$, and $3 \%$ of the dataset). Workers observed in two consecutive periods, either remaining in the same firm or switching firms (movers and stayers), have been kept for analysis. Given the aim of looking at wage ranks within the firm, a minimum firm size threshold had to be imposed. As such, only workers observed in firms with at least 10 workers were kept for analysis (dropping $22 \%$ of the observations). The final dataset under analysis includes 6,435,333 observations worker-year on 1,736,124 workers.

\section{Appendix: Additional tables}

\footnotetext{
${ }^{7}$ Workers cannot be classified whenever they are not observed the previous period (33\% of the observations), which can include: the first year the worker is observed in the dataset (in 1991, that holds for everyone) or whenever ( $\mathrm{s}$ )he is out of the labor market for some time, unemployed, or in a non-covered sector, such as public administration or self-employment.
} 


\begin{tabular}{|c|c|c|}
\hline Variable & Mean & Std. Dev. \\
\hline Change real hourly wage (log) & 0.04 & 0.17 \\
\hline Change wage rank & 1.03 & 16.02 \\
\hline Female & 0.38 & \\
\hline \multicolumn{3}{|l|}{ Education } \\
\hline less than high school & 0.79 & \\
\hline high school & 0.15 & \\
\hline university & 0.06 & \\
\hline Age & 38.34 & 10.69 \\
\hline Tenure (years, previous job) & 10.01 & 9.05 \\
\hline White collar & 0.42 & \\
\hline Mover & 0.03 & \\
\hline Firm closure & 0.01 & \\
\hline Change in firm size (log) & 0.01 & 0.4 \\
\hline Lisbon & 0.44 & \\
\hline \multicolumn{3}{|l|}{ Origin of capital } \\
\hline national & 0.78 & \\
\hline public & 0.10 & \\
\hline foreign & 0.11 & \\
\hline \multicolumn{3}{|l|}{ Industry } \\
\hline food, bev., tob. & 0.05 & \\
\hline textiles & 0.18 & \\
\hline wood & 0.03 & \\
\hline paper & 0.02 & \\
\hline chemicals & 0.03 & \\
\hline mineral products & 0.03 & \\
\hline metals & 0.04 & \\
\hline machinery & 0.07 & \\
\hline electric., gas, water & 0.02 & \\
\hline construction & 0.08 & \\
\hline trade & 0.14 & \\
\hline restaur., hotels & 0.04 & \\
\hline transp., communic. & 0.08 & \\
\hline banking, insurance & 0.08 & \\
\hline real estate, serv. co. & 0.04 & \\
\hline other serv. & 0.06 & \\
\hline other & 0.02 & \\
\hline $\mathrm{N}$ & \multicolumn{2}{|c|}{$6,435,333$} \\
\hline
\end{tabular}

Table 5: Descriptive statistics. 


\begin{tabular}{|c|c|c|c|c|}
\hline & \multicolumn{2}{|c|}{ Males } & \multicolumn{2}{|c|}{ Females } \\
\hline & wage & rank & wage & rank \\
\hline & $(1)$ & $(2)$ & $(3)$ & $(4)$ \\
\hline high school & $\begin{array}{l}.003 \\
(.002)\end{array}$ & $\begin{array}{c}-.183 \\
(.14)\end{array}$ & $\begin{array}{l}-.002 \\
(.002)\end{array}$ & $\begin{array}{l}-.251 \\
(.206)\end{array}$ \\
\hline university & $\begin{array}{c}.015^{* * *} \\
(.003)\end{array}$ & $\begin{array}{c}.916^{* * *} \\
(.269)\end{array}$ & $\begin{array}{c}.016^{* * *} \\
(.003)\end{array}$ & $\begin{array}{c}1.722^{* * *} \\
(.359)\end{array}$ \\
\hline age & $\begin{array}{c}-.004^{* * *} \\
(.0006)\end{array}$ & $\begin{array}{c}-.345^{* * *} \\
(.05)\end{array}$ & $\begin{array}{c}-.001^{* * *} \\
(.0007)\end{array}$ & $\begin{array}{c}-.392^{* * *} \\
(.078)\end{array}$ \\
\hline age sq. / 100 & $\begin{array}{c}.005^{* * *} \\
(.0003)\end{array}$ & $\begin{array}{c}.413^{* * *} \\
(.022)\end{array}$ & $\begin{array}{c}.003^{* * *} \\
(.0003)\end{array}$ & $\begin{array}{c}.645^{* * *} \\
(.035)\end{array}$ \\
\hline tenure (previous job) & $\begin{array}{c}-.001^{* * *} \\
(.00009)\end{array}$ & $\begin{array}{c}-.159^{* * *} \\
(.007)\end{array}$ & $\begin{array}{c}-.002^{* * *} \\
(.0001)\end{array}$ & $\begin{array}{c}-.237^{* * *} \\
(.011)\end{array}$ \\
\hline tenure sq. / 100 & $\begin{array}{c}.005^{* * *} \\
(.0003)\end{array}$ & $\begin{array}{c}.314^{* * *} \\
(.024)\end{array}$ & $\begin{array}{c}.008^{* * *} \\
(.0003)\end{array}$ & $\begin{array}{c}.688^{* * *} \\
(.04)\end{array}$ \\
\hline white collar & $\begin{array}{c}.005^{* * *} \\
(.0006)\end{array}$ & $\begin{array}{c}.344^{* * *} \\
(.05)\end{array}$ & $\begin{array}{l}.001^{* *} \\
(.0007)\end{array}$ & $\begin{array}{c}.461^{* * *} \\
(.083)\end{array}$ \\
\hline mover & $\begin{array}{c}.057^{* * *} \\
(.0007)\end{array}$ & $\begin{array}{c}-1.181^{* * *} \\
(.06)\end{array}$ & $\begin{array}{c}.051^{* * *} \\
(.0008)\end{array}$ & $\begin{array}{c}-2.65^{* * *} \\
(.098)\end{array}$ \\
\hline firm closure & $\begin{array}{c}-.043^{* * *} \\
(.002)\end{array}$ & $\begin{array}{c}-.906^{* * *} \\
(.167)\end{array}$ & $\begin{array}{c}-.039^{* * *} \\
(.002)\end{array}$ & $\begin{array}{l}.328 \\
(.209)\end{array}$ \\
\hline change in firm size (log) & $\begin{array}{c}-.005^{* * *} \\
(.0005)\end{array}$ & $\begin{array}{c}3.77^{* * *} \\
(.044)\end{array}$ & $\begin{array}{l}.001^{* *} \\
(.0006)\end{array}$ & $\begin{array}{c}3.861^{* * *} \\
(.065)\end{array}$ \\
\hline mover ${ }^{*}$ change firm size & $\begin{array}{l}.03^{* * *} \\
(.0006)\end{array}$ & $\begin{array}{c}-5.586^{* * *} \\
\quad(.052)\end{array}$ & $\begin{array}{c}.022^{* * *} \\
(.0007)\end{array}$ & $\begin{array}{c}-6.273^{* * *} \\
(.08)\end{array}$ \\
\hline Const. & $\begin{array}{c}.18^{* * *} \\
(.021)\end{array}$ & $\begin{array}{c}10.225^{* * *} \\
(1.7)\end{array}$ & $\begin{array}{c}.115^{* * *} \\
(.02)\end{array}$ & $\begin{array}{c}8.063^{* * *} \\
(2.328)\end{array}$ \\
\hline Obs. & $4,006,164$ & $4,006,164$ & $2,429,169$ & $2,429,169$ \\
\hline$\sigma_{\mu}$ & 0.13 & 11.06 & 0.11 & 12.30 \\
\hline$\sigma_{\varepsilon}$ & 0.19 & 15.66 & 0.15 & 17.74 \\
\hline$\rho$ & 0.32 & 0.33 & 0.32 & 0.33 \\
\hline
\end{tabular}

Table 6: Change in (LOG) WAGE And Change In RANK, BY Gender, Worker FIXed EFFECTS.

Note: Includes controls for year, industry (16 dummies), location (1 dummy), and the origin of the capital of the firm (2 dummies). Source: Computations based on Portugal, MTSS (1991-2000). 


\begin{tabular}{|c|c|c|c|c|c|c|}
\hline & below $\mathrm{h}$ & h school & higl & ichool & uni & ersity \\
\hline & wage & rank & wage & rank & wage & rank \\
\hline & $(1)$ & $(2)$ & (3) & $(4)$ & $(5)$ & $(6)$ \\
\hline age & $\begin{array}{c}-.003^{* * *} \\
(.0007)\end{array}$ & $\begin{array}{l}.3^{* * *} \\
(.057)\end{array}$ & $\begin{array}{c}-.007^{* * *} \\
(.002)\end{array}$ & $\begin{array}{c}.467^{* * *} \\
(.145)\end{array}$ & $\begin{array}{c}.015^{* * *} \\
(.003)\end{array}$ & $\begin{array}{c}-1.023^{* * *} \\
(.158)\end{array}$ \\
\hline age sq. / 100 & $\begin{array}{c}.004^{* * *} \\
(.0003)\end{array}$ & $\begin{array}{c}.352^{* * *} \\
(.024)\end{array}$ & $\begin{array}{c}.01^{* * *} \\
(.001)\end{array}$ & $\begin{array}{c}.586^{* * *} \\
(.076)\end{array}$ & $\begin{array}{c}.019^{* * *} \\
(.002)\end{array}$ & $\begin{array}{c}1.335^{* * *} \\
(.076)\end{array}$ \\
\hline tenure (previous job) & $\begin{array}{c}-.001^{* * *} \\
(.00009)\end{array}$ & $\begin{array}{c}-.164^{* * *} \\
(.008)\end{array}$ & $\begin{array}{c}-.002^{* * *} \\
(.0003)\end{array}$ & $\begin{array}{c}-.168^{* * *} \\
(.022)\end{array}$ & $\begin{array}{l}.0005 \\
(.0005)\end{array}$ & $\begin{array}{l}.018 \\
(.022)\end{array}$ \\
\hline tenure sq. / 100 & $\begin{array}{c}.004^{* * *} \\
(.0003)\end{array}$ & $\begin{array}{c}.309^{* * *} \\
(.026)\end{array}$ & $\begin{array}{c}.012^{* * *} \\
(.001)\end{array}$ & $\begin{array}{c}.499^{* * *} \\
(.082)\end{array}$ & $\begin{array}{c}-.005^{* * *} \\
(.002)\end{array}$ & $\begin{array}{c}-.251^{* * *} \\
(.079)\end{array}$ \\
\hline white collar & $\begin{array}{c}.008^{* * *} \\
(.0007)\end{array}$ & $\begin{array}{c}.479^{* * *} \\
(.061)\end{array}$ & $\begin{array}{c}.011^{* * *} \\
(.002)\end{array}$ & $\begin{array}{c}.277^{* *} \\
(.117)\end{array}$ & $\begin{array}{c}-.007^{* * *} \\
(.002)\end{array}$ & $\begin{array}{l}.034 \\
(.11)\end{array}$ \\
\hline mover & $\begin{array}{c}.036^{* * *} \\
(.0008)\end{array}$ & $\begin{array}{c}-1.421^{* * *} \\
(.074)\end{array}$ & $\begin{array}{c}.102^{* * *} \\
(.002)\end{array}$ & $\begin{array}{c}-1.8^{* * *} \\
(.131)\end{array}$ & $\begin{array}{c}.106^{* * *} \\
(.003)\end{array}$ & $\begin{array}{c}1.522^{* * *} \\
(.121)\end{array}$ \\
\hline firm closure & $\begin{array}{c}-.024^{* * *} \\
(.002)\end{array}$ & $\begin{array}{c}-1.062^{* * *} \\
(.198)\end{array}$ & $\begin{array}{c}-.082^{* * *} \\
(.006)\end{array}$ & $\begin{array}{l}.645 \\
(.401)\end{array}$ & $\begin{array}{c}-.085^{* * *} \\
(.008)\end{array}$ & $\begin{array}{c}-1.408^{* * *} \\
(.398)\end{array}$ \\
\hline change in firm size (log) & $\begin{array}{c}-.011^{* * *} \\
(.0006)\end{array}$ & $\begin{array}{c}3.872^{\text {*** }} \\
(.052)\end{array}$ & $\begin{array}{c}.014^{* * *} \\
(.002)\end{array}$ & $\begin{array}{c}3.707^{* * *} \\
(.111)\end{array}$ & $\begin{array}{c}.018^{* * *} \\
(.002)\end{array}$ & $\begin{array}{c}2.754^{* * *} \\
(.107)\end{array}$ \\
\hline mover ${ }^{*}$ change firm size & $\begin{array}{c}.035^{* * *} \\
(.0007)\end{array}$ & $\begin{array}{c}-5.864^{* * *} \\
(.063)\end{array}$ & $\begin{array}{c}.014^{* * *} \\
(.002)\end{array}$ & $\begin{array}{c}-6.414^{* * *} \\
(.125)\end{array}$ & $\begin{array}{l}.003 \\
(.003)\end{array}$ & $\begin{array}{c}-2.375^{* * *} \\
(.12)\end{array}$ \\
\hline Const. & $\begin{array}{c}.15^{* * *} \\
(.023)\end{array}$ & $\begin{array}{c}8.929^{* * *} \\
(1.974)\end{array}$ & $\begin{array}{c}.239^{* * *} \\
(.059)\end{array}$ & $\begin{array}{c}14.849^{* * *} \\
(4.185)\end{array}$ & $\begin{array}{c}.413^{* * *} \\
(.107)\end{array}$ & $\begin{array}{c}23.385^{\text {*** }} \\
\quad(5.026)\end{array}$ \\
\hline Obs. & $3,204,501$ & $3,204,501$ & 554,463 & 554,463 & 247,200 & 247,200 \\
\hline$\sigma_{\mu}$ & 0.13 & 11.17 & 0.151 & 11.89 & 0.17 & 9.85 \\
\hline$\sigma_{\varepsilon}$ & 0.18 & 16.14 & 0.21 & 14.7 & 0.22 & 10.21 \\
\hline$\rho$ & 0.32 & 0.32 & 0.35 & 0.40 & 0.36 & 0.48 \\
\hline
\end{tabular}

Table 7: Change in (log) Wage and change in Rank, By education, males, worker FIXED EFFECTS.

Note: Includes controls for year, industry (16 dummies), location (1 dummy), and the origin of the capital of the firm (2 dummies). Source: Computations based on Portugal, MTSS (1991-2000). 


\begin{tabular}{|c|c|c|c|c|c|c|}
\hline & \multicolumn{2}{|c|}{ below high school } & \multicolumn{2}{|c|}{ high school } & \multicolumn{2}{|c|}{ university } \\
\hline & wage & rank & wage & rank & wage & rank \\
\hline & $(1)$ & $(2)$ & $(3)$ & $(4)$ & $(5)$ & $(6)$ \\
\hline age & $\begin{array}{c}-.001^{* * *} \\
(.0007)\end{array}$ & $\begin{array}{c}-.357^{* * *} \\
(.09)\end{array}$ & $\begin{array}{l}-.002 \\
(.002)\end{array}$ & $\begin{array}{c}-.608^{* * *} \\
(.194)\end{array}$ & $\begin{array}{c}-.01^{* *} \\
(.004)\end{array}$ & $\begin{array}{c}-.889^{* * *} \\
(.277)\end{array}$ \\
\hline age sq. / 100 & $\begin{array}{c}.002^{* * *} \\
(.0003)\end{array}$ & $\begin{array}{c}.653^{* * *} \\
(.04)\end{array}$ & $\begin{array}{c}.007^{* * *} \\
(.001)\end{array}$ & $\begin{array}{c}.612^{* * *} \\
(.114)\end{array}$ & $\begin{array}{c}.016^{* * *} \\
(.002)\end{array}$ & $\begin{array}{c}1.339^{* * *} \\
(.154)\end{array}$ \\
\hline tenure (previous job) & $\begin{array}{c}-.002^{* * *} \\
(.0001)\end{array}$ & $\begin{array}{c}-.25^{* * *} \\
(.013)\end{array}$ & $\begin{array}{c}-.002^{* * *} \\
(.0003)\end{array}$ & $\begin{array}{c}-.227^{* * *} \\
(.031)\end{array}$ & $\begin{array}{r}-.0007 \\
(.0006)\end{array}$ & $\begin{array}{l}-.04 \\
(.041)\end{array}$ \\
\hline tenure sq. / 100 & $\begin{array}{c}.007^{* * *} \\
(.0004)\end{array}$ & $\begin{array}{c}.723^{* * *} \\
(.045)\end{array}$ & $\begin{array}{c}.013^{* * *} \\
(.001)\end{array}$ & $\begin{array}{c}.751^{* * *} \\
(.129)\end{array}$ & $\begin{array}{r}-.002 \\
(.003)\end{array}$ & $\begin{array}{l}-.008 \\
(.169)\end{array}$ \\
\hline white collar & $\begin{array}{c}.007^{* * *} \\
(.0008)\end{array}$ & $\begin{array}{c}.624^{* * *} \\
(.103)\end{array}$ & $\begin{array}{c}.006^{* * *} \\
(.002)\end{array}$ & $\begin{array}{l}.103 \\
(.18)\end{array}$ & $\begin{array}{c}-.017^{* * *} \\
(.003)\end{array}$ & $\begin{array}{c}-.384^{*} \\
(.198)\end{array}$ \\
\hline mover & $\begin{array}{c}.033^{* * *} \\
(.001)\end{array}$ & $\begin{array}{c}-2.381^{* * *} \\
(.125)\end{array}$ & $\begin{array}{c}.076^{* * *} \\
(.002)\end{array}$ & $\begin{array}{c}-4.424^{* * *} \\
(.184)\end{array}$ & $\begin{array}{c}.101^{* * *} \\
(.003)\end{array}$ & $\begin{array}{c}-.648^{* * *} \\
(.211)\end{array}$ \\
\hline firm closure & $\begin{array}{c}-.025^{* * *} \\
(.002)\end{array}$ & $\begin{array}{l}-.215 \\
(.249)\end{array}$ & $\begin{array}{c}-.062^{* * *} \\
(.005)\end{array}$ & $\begin{array}{c}3.33^{* * *} \\
(.465)\end{array}$ & $\begin{array}{c}-.054^{* * *} \\
(.009)\end{array}$ & $\begin{array}{l}.842 \\
(.596)\end{array}$ \\
\hline change in firm size (log) & $\begin{array}{c}-.001^{* * *} \\
(.0006)\end{array}$ & $\begin{array}{c}3.815^{\text {*** }} \\
(.079)\end{array}$ & $\begin{array}{c}.014^{* * *} \\
(.001)\end{array}$ & $\begin{array}{c}4.265^{\text {*** }} \\
(.13)\end{array}$ & $\begin{array}{c}.01^{* * *} \\
(.003)\end{array}$ & $\begin{array}{c}3.022^{\text {*** }} \\
(.172)\end{array}$ \\
\hline mover ${ }^{*}$ change firm size & $\begin{array}{c}.026^{* * *} \\
(.0008)\end{array}$ & $\begin{array}{c}-7.038^{* * *} \\
(.101)\end{array}$ & $\begin{array}{c}.009^{* * *} \\
(.002)\end{array}$ & $\begin{array}{c}-5.922^{* * *} \\
(.153)\end{array}$ & $\begin{array}{c}.011^{* * *} \\
(.003)\end{array}$ & $\begin{array}{c}-3.454^{* * *} \\
(.197)\end{array}$ \\
\hline Const. & $\begin{array}{c}.106^{* * *} \\
(.022)\end{array}$ & $\begin{array}{c}6.181^{* *} \\
(2.777)\end{array}$ & $\begin{array}{l}.13^{* *} \\
(.057)\end{array}$ & $\begin{array}{c}16.916^{* * *} \\
(5.04)\end{array}$ & $\begin{array}{c}.299^{* *} \\
(.119)\end{array}$ & $\begin{array}{c}20.62^{* * *} \\
(7.583)\end{array}$ \\
\hline Obs. & $1,869,928$ & $1,869,928$ & 403,634 & 403,634 & 155,607 & 155,607 \\
\hline$\sigma_{\mu}$ & 0.10 & 12.48 & 0.13 & 12.55 & 0.15 & 11.40 \\
\hline$\sigma_{\varepsilon}$ & 0.15 & 18.56 & 0.17 & 15.34 & 0.19 & 12.17 \\
\hline$\rho$ & 0.31 & 0.31 & 0.36 & 0.40 & 0.37 & 0.47 \\
\hline
\end{tabular}

Table 8: Change in (LOG) Wage And Change in RAnk, By Education, Females, worker FIXED EFFECTS.

Note: Includes controls for year, industry (16 dummies), location ( 1 dummy), and the origin of the capital of the firm (2 dummies). Source: Computations based on Portugal, MTSS (1991-2000). 


\begin{tabular}{|c|c|c|c|c|c|}
\hline independent variable & $(1)$ & $(2)$ & $(3)$ & $(4)$ & $(5)$ \\
\hline high school & $\begin{array}{l}-.045 \\
(.187)\end{array}$ & $\begin{array}{c}.199 \\
(.15)\end{array}$ & $\begin{array}{c}-.156 \\
(.15)\end{array}$ & $\begin{array}{l}-.048 \\
(.145)\end{array}$ & $\begin{array}{l}.051 \\
(.145)\end{array}$ \\
\hline university & $\begin{array}{c}1.511^{* * *} \\
(.317)\end{array}$ & $\begin{array}{c}.806^{* * *} \\
(.253)\end{array}$ & $\begin{array}{c}.948^{* * *} \\
(.254)\end{array}$ & $\begin{array}{l}1.285^{* * *} \\
(.245)\end{array}$ & $\begin{array}{c}1.198^{* * *} \\
(.245)\end{array}$ \\
\hline age & $\begin{array}{c}-.351^{* * *} \\
(.063)\end{array}$ & $\begin{array}{c}-.197^{* * *} \\
(.05)\end{array}$ & $\begin{array}{c}-.169^{* * *} \\
(.051)\end{array}$ & $\begin{array}{l}-.013 \\
(.049)\end{array}$ & $\begin{array}{l}-.02 \\
(.049)\end{array}$ \\
\hline age sq. / 100 & $\begin{array}{c}.376^{* * *} \\
(.031)\end{array}$ & $\begin{array}{c}.203^{* * *} \\
(.025)\end{array}$ & $\begin{array}{c}.171^{* * *} \\
(.025)\end{array}$ & $\begin{array}{l}-.013 \\
(.024)\end{array}$ & $\begin{array}{l}-.004 \\
(.024)\end{array}$ \\
\hline tenure (previous job) & $\begin{array}{c}-.118^{* * *} \\
(.011)\end{array}$ & $\begin{array}{c}-.06^{* * *} \\
(.009)\end{array}$ & $\begin{array}{c}-.058^{* * *} \\
(.009)\end{array}$ & $\begin{array}{c}-.017^{* *} \\
(.009)\end{array}$ & $\begin{array}{c}-.023^{* * *} \\
(.009)\end{array}$ \\
\hline tenure sq. / 100 & $\begin{array}{c}.312^{* * *} \\
(.031)\end{array}$ & $\begin{array}{l}.021 \\
(.025)\end{array}$ & $\begin{array}{l}.015 \\
(.025)\end{array}$ & $\begin{array}{c}-.077^{* * *} \\
(.024)\end{array}$ & $\begin{array}{c}-.07^{* * *} \\
(.024)\end{array}$ \\
\hline white collar & $\begin{array}{c}.416^{* * *} \\
(.06)\end{array}$ & $\begin{array}{l}.061 \\
(.048)\end{array}$ & $\begin{array}{l}.09^{*} \\
(.048)\end{array}$ & $\begin{array}{l}.059 \\
(.046)\end{array}$ & $\begin{array}{l}.065 \\
(.046)\end{array}$ \\
\hline mover & $\begin{array}{c}-1.444^{* * *} \\
(.115)\end{array}$ & $\begin{array}{c}-2.652^{* * *} \\
(.097)\end{array}$ & $\begin{array}{c}-2.677^{* * *} \\
(.097)\end{array}$ & $\begin{array}{c}-3.253^{* * *} \\
(.094)\end{array}$ & $\begin{array}{c}-25.685^{* * *} \\
(.943)\end{array}$ \\
\hline firm closure & $\begin{array}{c}1.127^{* * *} \\
(.363)\end{array}$ & $\begin{array}{c}2.606^{* * *} \\
(.291)\end{array}$ & $\begin{array}{c}2.651^{* * *} \\
(.291)\end{array}$ & $\begin{array}{l}3.166^{* * *} \\
(.281)\end{array}$ & $\begin{array}{c}2.044^{* * *} \\
(.282)\end{array}$ \\
\hline change in firm size (log) & $\begin{array}{c}3.693^{* * *} \\
(.063)\end{array}$ & $\begin{array}{c}4.74^{* * *} \\
(.05)\end{array}$ & $\begin{array}{c}4.741^{* * *} \\
(.05)\end{array}$ & $\begin{array}{l}4.925^{* * *} \\
(.049)\end{array}$ & $\begin{array}{l}4.929^{* * *} \\
(.049)\end{array}$ \\
\hline mover ${ }^{*}$ change firm size & $\begin{array}{c}-5.662^{* * *} \\
(.095)\end{array}$ & $\begin{array}{c}-6.973^{* * *} \\
(.076)\end{array}$ & $\begin{array}{c}-6.979^{* * *} \\
(.076)\end{array}$ & $\begin{array}{c}-7.518^{* * *} \\
(.074)\end{array}$ & $\begin{array}{c}-7.141^{* * *} \\
(.074)\end{array}$ \\
\hline change real wage (log) & & $\begin{array}{l}48.945^{* * *} \\
\quad(.052)\end{array}$ & $\begin{array}{c}48.478^{* * *} \\
(.065)\end{array}$ & $\begin{array}{c}213.991^{* * *} \\
(.504)\end{array}$ & $\begin{array}{c}219.08^{* * *} \\
(.516)\end{array}$ \\
\hline mover ${ }^{*}$ wage change & & $\begin{array}{c}-17.669^{* * *} \\
(.241)\end{array}$ & $\begin{array}{c}-17.699^{* * *} \\
(.241)\end{array}$ & $\begin{array}{c}-22.547^{* * *} \\
(.234)\end{array}$ & $\begin{array}{c}-117.221^{* * *} \\
(2.395)\end{array}$ \\
\hline init. wage & & & $\begin{array}{c}-.922^{* * *} \\
(.077)\end{array}$ & $\begin{array}{c}-1.694^{* * *} \\
(.074)\end{array}$ & $\begin{array}{c}-1.84^{* * *} \\
(.074)\end{array}$ \\
\hline init. wage ${ }^{*} \mathrm{w}$ change & & & & $\begin{array}{c}-23.482^{* * *} \\
\quad(.071)\end{array}$ & $\begin{array}{c}-24.212^{* * *} \\
(.073)\end{array}$ \\
\hline mover $*$ init. wage & & & & & $\begin{array}{c}3.389^{* * *} \\
(.137)\end{array}$ \\
\hline mover $*$ init. $\mathrm{w}^{*} \mathrm{w}$ change & & & & & $\begin{array}{c}13.899^{* * *} \\
(.344)\end{array}$ \\
\hline Const. & $\begin{array}{c}9.698^{* * *} \\
(2.177)\end{array}$ & $\begin{array}{l}2.846 \\
(1.74)\end{array}$ & $\begin{array}{c}8.469^{* * *} \\
(1.802)\end{array}$ & $\begin{array}{c}9.37^{* * *} \\
(1.744)\end{array}$ & $\begin{array}{c}10.541^{* * *} \\
(1.742)\end{array}$ \\
\hline Obs. & $2,178,528$ & $2,178,528$ & $2,178,528$ & $2,178,528$ & $2,178,528$ \\
\hline$\sigma_{\mu}$ & 9.99 & 8.03 & 8.03 & 7.87 & 7.87 \\
\hline$\sigma_{\varepsilon}$ & 14.31 & 11.44 & 11.44 & 11.01 & 11.06 \\
\hline$\rho$ & 0.33 & 0.33 & 0.33 & 0.34 & 0.34 \\
\hline
\end{tabular}

Table 9: ChAnge in RANK, WORKER FiXed EFFECTs, MALES, FIRMS LARGER THAN 100 WORKERS.

Note: Includes controls for year, industry (16 dummies), location (1 dummy), and the origin of the capital of the firm (2 dummies). Source: Computations based on Portugal, MTSS (1991-2000). 


\begin{tabular}{|c|c|c|c|c|c|}
\hline independent variable & $(1)$ & $(2)$ & $(3)$ & $(4)$ & $(5)$ \\
\hline high school & $\begin{array}{l}-.437 \\
(.304)\end{array}$ & $\begin{array}{c}-.507^{* *} \\
(.249)\end{array}$ & $\begin{array}{c}-.501^{* *} \\
(.249)\end{array}$ & $\begin{array}{l}-.409^{*} \\
(.244)\end{array}$ & $\begin{array}{l}.417^{*} \\
(.244)\end{array}$ \\
\hline university & $\begin{array}{l}1.787^{* * *} \\
\quad(.478)\end{array}$ & $\begin{array}{l}.706^{*} \\
(.392)\end{array}$ & $\begin{array}{l}.733^{*} \\
(.393)\end{array}$ & $\begin{array}{c}1.274^{* * *} \\
(.384)\end{array}$ & $\begin{array}{c}1.235^{* * *} \\
(.384)\end{array}$ \\
\hline age & $\begin{array}{c}-.373^{* * *} \\
(.105)\end{array}$ & $\begin{array}{c}-.229^{* * *} \\
(.086)\end{array}$ & $\begin{array}{c}-.227^{* * *} \\
(.086)\end{array}$ & $\begin{array}{l}-.07 \\
(.084)\end{array}$ & $\begin{array}{l}-.073 \\
(.084)\end{array}$ \\
\hline age sq. / 100 & $\begin{array}{c}.546^{* * *} \\
(.053)\end{array}$ & $\begin{array}{c}.444^{* * *} \\
(.044)\end{array}$ & $\begin{array}{c}.442^{* * *} \\
(.044)\end{array}$ & $\begin{array}{c}.258^{* * *} \\
(.043)\end{array}$ & $\begin{array}{c}.262^{* * *} \\
(.043)\end{array}$ \\
\hline tenure (previous job) & $\begin{array}{c}-.233^{* * *} \\
(.019)\end{array}$ & $\begin{array}{c}-.049^{* * *} \\
(.015)\end{array}$ & $\begin{array}{c}-.048^{* * *} \\
(.015)\end{array}$ & $\begin{array}{l}.02 \\
(.015)\end{array}$ & $\begin{array}{l}.022 \\
(.015)\end{array}$ \\
\hline tenure sq. / 100 & $\begin{array}{c}.793^{* * *} \\
(.055)\end{array}$ & $\begin{array}{l}.103^{* *} \\
(.045)\end{array}$ & $\begin{array}{c}.098^{* *} \\
(.045)\end{array}$ & $\begin{array}{c}-.129^{* * *} \\
(.044)\end{array}$ & $\begin{array}{c}-.132^{* * *} \\
(.044)\end{array}$ \\
\hline white collar & $\begin{array}{l}.177 \\
(.113)\end{array}$ & $\begin{array}{l}.095 \\
(.093)\end{array}$ & $\begin{array}{l}.101 \\
(.093)\end{array}$ & $\begin{array}{l}-.021 \\
(.091)\end{array}$ & $\begin{array}{l}-.012 \\
(.091)\end{array}$ \\
\hline mover & $\begin{array}{c}-3.184^{* * *} \\
(.186)\end{array}$ & $\begin{array}{c}-5.346^{* * *} \\
(.162)\end{array}$ & $\begin{array}{c}-5.35^{* * *} \\
(.163)\end{array}$ & $\begin{array}{c}-5.68^{* * *} \\
(.159)\end{array}$ & $\begin{array}{c}-18.948^{* * *} \\
(1.63)\end{array}$ \\
\hline firm closure & $\begin{array}{c}1.739^{* * *} \\
(.422)\end{array}$ & $\begin{array}{c}3.134^{* * *} \\
(.347)\end{array}$ & $\begin{array}{c}3.137^{* * *} \\
(.347)\end{array}$ & $\begin{array}{c}3.19^{* * * *} \\
(.34)\end{array}$ & $\begin{array}{c}2.96^{* * *} \\
(.34)\end{array}$ \\
\hline change in firm size (log) & $\begin{array}{c}5.308^{* * *} \\
(.099)\end{array}$ & $\begin{array}{c}5.327^{* * *} \\
(.081)\end{array}$ & $\begin{array}{c}5.329^{* * *} \\
(.081)\end{array}$ & $\begin{array}{c}5.351^{* * *} \\
(.08)\end{array}$ & $\begin{array}{c}5.341^{* * *} \\
(.08)\end{array}$ \\
\hline mover ${ }^{*}$ change firm size & $\begin{array}{c}-7.477^{* * *} \\
(.151)\end{array}$ & $\begin{array}{c}-8.497^{* * *} \\
(.125)\end{array}$ & $\begin{array}{c}-8.499^{* * *} \\
(.125)\end{array}$ & $\begin{array}{c}-8.821^{* * *} \\
(.122)\end{array}$ & $\begin{array}{c}-8.666^{* * *} \\
(.122)\end{array}$ \\
\hline change real wage (log) & & $\begin{array}{l}62.509^{* * *} \\
\quad(.098)\end{array}$ & $\begin{array}{c}62.419^{* * *} \\
\quad(.126)\end{array}$ & $\begin{array}{c}245.911^{* * *} \\
(.946)\end{array}$ & $\begin{array}{c}247.924^{* * *} \\
(.962)\end{array}$ \\
\hline mover ${ }^{*}$ wage change & & $\begin{array}{c}-15.23^{* * *} \\
(.528)\end{array}$ & $\begin{array}{c}-15.24^{* * *} \\
(.528)\end{array}$ & $\begin{array}{c}-19.876^{* * *} \\
(.517)\end{array}$ & $\begin{array}{c}-70.634^{* * *} \\
(5.406)\end{array}$ \\
\hline init. wage & & & $\begin{array}{l}-.173 \\
(.153)\end{array}$ & $\begin{array}{c}-2.416^{* * *} \\
(.15)\end{array}$ & $\begin{array}{c}-2.503^{* * *} \\
(.15)\end{array}$ \\
\hline init. wage ${ }^{*} \mathrm{w}$ change & & & & $\begin{array}{c}-27.346^{* * *} \\
(.14)\end{array}$ & $\begin{array}{c}-27.65^{* * *} \\
(.142)\end{array}$ \\
\hline mover $*$ init. wage & & & & & $\begin{array}{c}2.087^{* * *} \\
(.25)\end{array}$ \\
\hline mover $*$ init. $\mathrm{w}^{*} \mathrm{w}$ change & & & & & $\begin{array}{c}7.743^{* * *} \\
(.811)\end{array}$ \\
\hline Const. & $\begin{array}{c}8.086^{* *} \\
(3.186)\end{array}$ & $\begin{array}{c}.959 \\
(2.613)\end{array}$ & $\begin{array}{l}2.043 \\
(2.781)\end{array}$ & $\begin{array}{c}12.559^{* * *} \\
(2.721)\end{array}$ & $\begin{array}{c}13.18^{* * *} \\
(2.721)\end{array}$ \\
\hline Obs. & $1,201,823$ & $1,201,823$ & $1,201,823$ & $1,201,823$ & $1,201,823$ \\
\hline$\sigma_{\mu}$ & 11.57 & 9.38 & 9.37 & 9.27 & 9.27 \\
\hline$\sigma_{\varepsilon}$ & 16.49 & 13.52 & 13.52 & 13.20 & 13.23 \\
\hline$\rho$ & 0.33 & 0.32 & 0.32 & 0.33 & 0.33 \\
\hline
\end{tabular}

Table 10: Change in RANK, WORKER FiXed EFfECts, FEMAles, FIRMs LARger than 100 WORKERS.

Note: Includes controls for year, industry (16 dummies), location (1 dummy), and the origin of the capital of the firm (2 dummies). Source: Computations based on Portugal, MTSS (1991-2000). 


\begin{tabular}{|c|c|c|c|c|c|}
\hline independent variable & $(1)$ & $(2)$ & $(3)$ & $(4)$ & $(5)$ \\
\hline age & $\begin{array}{c}-.264^{* * *} \\
(.074)\end{array}$ & $\begin{array}{c}-.178^{* * *} \\
(.058)\end{array}$ & $\begin{array}{c}.159^{* * *} \\
(.058)\end{array}$ & $\begin{array}{l}-.009 \\
(.057)\end{array}$ & $\begin{array}{l}-.013 \\
(.057)\end{array}$ \\
\hline age sq. / 100 & $\begin{array}{c}.264^{* * *} \\
(.036)\end{array}$ & $\begin{array}{c}.174^{* * *} \\
(.028)\end{array}$ & $\begin{array}{c}.152^{* * *} \\
(.028)\end{array}$ & $\begin{array}{r}-.016 \\
(.028)\end{array}$ & $\begin{array}{l}-.011 \\
(.028)\end{array}$ \\
\hline tenure (previous job) & $\begin{array}{c}-.139^{* * *} \\
(.013)\end{array}$ & $\begin{array}{c}-.082^{* * *} \\
(.01)\end{array}$ & $\begin{array}{c}-.078^{* * *} \\
(.011)\end{array}$ & $\begin{array}{c}-.036^{* * *} \\
(.01)\end{array}$ & $\begin{array}{c}-.039^{* * *} \\
(.01)\end{array}$ \\
\hline tenure sq. / 100 & $\begin{array}{c}.336^{* * *} \\
(.036)\end{array}$ & $\begin{array}{l}.052^{*} \\
(.028)\end{array}$ & $\begin{array}{l}.048^{*} \\
(.028)\end{array}$ & $\begin{array}{l}-.033 \\
(.027)\end{array}$ & $\begin{array}{c}-.034 \\
(.027)\end{array}$ \\
\hline white collar & $\begin{array}{c}.544^{* * *} \\
(.075)\end{array}$ & $\begin{array}{l}-.093 \\
(.059)\end{array}$ & $\begin{array}{l}-.072 \\
(.059)\end{array}$ & $\begin{array}{l}.025 \\
(.058)\end{array}$ & $\begin{array}{l}.024 \\
(.058)\end{array}$ \\
\hline mover & $\begin{array}{c}-2.814^{* * *} \\
(.159)\end{array}$ & $\begin{array}{c}-3.198^{* * *} \\
\quad(.128)\end{array}$ & $\begin{array}{c}-3.225^{* * *} \\
(.128)\end{array}$ & $\begin{array}{c}-4.028^{* * *} \\
(.125)\end{array}$ & $\begin{array}{c}-24.133^{* * *} \\
(1.789)\end{array}$ \\
\hline firm closure & $\begin{array}{l}-.101 \\
(.501)\end{array}$ & $\begin{array}{l}.296 \\
(.395)\end{array}$ & $\begin{array}{l}.322 \\
(.395)\end{array}$ & $\begin{array}{c}1.176^{* * *} \\
(.385)\end{array}$ & $\begin{array}{l}.26 \\
(.389)\end{array}$ \\
\hline change in firm size (log) & $\begin{array}{l}3.881^{* * *} \\
(.076)\end{array}$ & $\begin{array}{c}5.761^{* * *} \\
(.06)\end{array}$ & $\begin{array}{c}5.761^{* * *} \\
(.06)\end{array}$ & $\begin{array}{c}5.828^{* * *} \\
(.059)\end{array}$ & $\begin{array}{c}5.827^{* * *} \\
\quad(.059)\end{array}$ \\
\hline mover ${ }^{*}$ change firm size & $\begin{array}{c}-5.537^{* * *} \\
(.13)\end{array}$ & $\begin{array}{c}-7.76^{* * *} \\
(.103)\end{array}$ & $\begin{array}{c}-7.762^{* * *} \\
(.103)\end{array}$ & $\begin{array}{c}-8.058^{* * *} \\
(.1)\end{array}$ & $\begin{array}{c}-7.897^{* * *} \\
(.101)\end{array}$ \\
\hline change real wage (log) & & $\begin{array}{c}53.577^{* * *} \\
(.062)\end{array}$ & $\begin{array}{c}53.12^{* * *} \\
\quad(.078)\end{array}$ & $\begin{array}{c}216.455^{* * *} \\
(.671)\end{array}$ & $\begin{array}{c}217.924^{* * *} \\
(.681)\end{array}$ \\
\hline mover $*$ wage change & & $\begin{array}{c}-17.141^{* * *} \\
(.33)\end{array}$ & $\begin{array}{c}-17.173^{* * *} \\
(.33)\end{array}$ & $\begin{array}{c}-24.118^{* * *} \\
(.324)\end{array}$ & $\begin{array}{c}-69.282^{* * *} \\
(3.85)\end{array}$ \\
\hline init. wage & & & $\begin{array}{c}-.908^{* * *} \\
(.095)\end{array}$ & $\begin{array}{c}-2.626^{* * *} \\
(.093)\end{array}$ & $\begin{array}{c}-2.669^{* * *} \\
(.093)\end{array}$ \\
\hline init. wage ${ }^{*} \mathrm{w}$ change & & & & $\begin{array}{c}-23.734^{* * *} \\
(.097)\end{array}$ & $\begin{array}{c}-23.95^{* * *} \\
(.098)\end{array}$ \\
\hline mover $*$ init. wage & & & & & $\begin{array}{c}3.161^{* * *} \\
(.273)\end{array}$ \\
\hline mover ${ }^{*}$ init. $\mathrm{w}^{*} \mathrm{w}$ change & & & & & $\begin{array}{c}6.998^{* * *} \\
\quad(.574)\end{array}$ \\
\hline Const. & $\begin{array}{c}7.906^{* * *} \\
(2.633)\end{array}$ & $\begin{array}{l}2.414 \\
(2.071)\end{array}$ & $\begin{array}{c}7.997^{* * *} \\
(2.152)\end{array}$ & $\begin{array}{c}15.072^{* * *} \\
(2.101)\end{array}$ & $\begin{array}{c}15.46^{* * *} \\
(2.101)\end{array}$ \\
\hline Obs. & $1,662,612$ & $1,662,612$ & $1,662,612$ & $1,662,612$ & $1,662,612$ \\
\hline$\sigma_{\mu}$ & 10.21 & 8.13 & 8.12 & 8.04 & 8.04 \\
\hline$\sigma_{\varepsilon}$ & 14.99 & 11.80 & 11.80 & 11.52 & 11.52 \\
\hline$\rho$ & 0.32 & 0.32 & 0.32 & 0.33 & 0.33 \\
\hline
\end{tabular}

Table 11: Change in RANK, WORKer FIXed EFFECTS, MAles, Below High SCHOOL, FiRmS LARGER THAN 100 WORKERS.

Note: Includes controls for year, industry (16 dummies), location (1 dummy), and the origin of the capital of the firm (2 dummies). Source: Computations based on Portugal, MTSS (1991-2000). 


\begin{tabular}{|c|c|c|c|c|c|}
\hline independent variable & $(1)$ & $(2)$ & $(3)$ & $(4)$ & $(5)$ \\
\hline age & $\begin{array}{c}.61^{* * *} \\
(.161)\end{array}$ & $\begin{array}{c}.263^{* *} \\
(.129)\end{array}$ & $\begin{array}{l}-.211 \\
(.129)\end{array}$ & $\begin{array}{l}-.047 \\
(.126)\end{array}$ & $\begin{array}{l}-.081 \\
(.125)\end{array}$ \\
\hline age sq. / 100 & $\begin{array}{c}.788^{* * *} \\
(.091)\end{array}$ & $\begin{array}{c}.385^{* * *} \\
(.074)\end{array}$ & $\begin{array}{c}.318^{* * *} \\
(.074)\end{array}$ & $\begin{array}{l}.075 \\
(.072)\end{array}$ & $\begin{array}{l}.107 \\
(.072)\end{array}$ \\
\hline tenure (previous job) & $\begin{array}{l}-.038 \\
(.029)\end{array}$ & $\begin{array}{l}.039^{*} \\
(.023)\end{array}$ & $\begin{array}{l}.033 \\
(.023)\end{array}$ & $\begin{array}{c}.08^{* * *} \\
(.022)\end{array}$ & $\begin{array}{l}.042^{*} \\
(.022)\end{array}$ \\
\hline tenure sq. / 100 & $\begin{array}{c}.274^{* * *} \\
(.093)\end{array}$ & $\begin{array}{c}-.15^{* *} \\
(.075)\end{array}$ & $\begin{array}{c}-.145^{*} \\
(.075)\end{array}$ & $\begin{array}{c}-.223^{* * *} \\
(.073)\end{array}$ & $\begin{array}{c}-.217^{* * *} \\
(.072)\end{array}$ \\
\hline white collar & $\begin{array}{c}.355^{* * *} \\
(.137)\end{array}$ & $\begin{array}{c}-.182^{*} \\
(.11)\end{array}$ & $\begin{array}{c}-.168 \\
(.11)\end{array}$ & $\begin{array}{c}-.274^{* *} \\
(.107)\end{array}$ & $\begin{array}{c}-.262^{* *} \\
(.106)\end{array}$ \\
\hline mover & $\begin{array}{c}-1.653^{* * *} \\
(.213)\end{array}$ & $\begin{array}{c}-4.085^{* * *} \\
(.193)\end{array}$ & $\begin{array}{c}-4.097^{* * *} \\
(.193)\end{array}$ & $\begin{array}{c}-4.271^{* * *} \\
(.187)\end{array}$ & $\begin{array}{c}-32.607^{* * *} \\
(2.115)\end{array}$ \\
\hline firm closure & $\begin{array}{c}5.472^{* * *} \\
(.664)\end{array}$ & $\begin{array}{c}8.139^{* * *} \\
(.537)\end{array}$ & $\begin{array}{c}8.213^{* * *} \\
(.537)\end{array}$ & $\begin{array}{c}8.83^{* * *} \\
(.522)\end{array}$ & $\begin{array}{c}6.838^{* * *} \\
(.523)\end{array}$ \\
\hline change in firm size (log) & $\begin{array}{c}3.337^{* * *} \\
(.141)\end{array}$ & $\begin{array}{c}2.648^{* * *} \\
(.113)\end{array}$ & $\begin{array}{c}2.652^{* * *} \\
(.113)\end{array}$ & $\begin{array}{c}2.604^{* * *} \\
(.11)\end{array}$ & $\begin{array}{c}2.576^{* * *} \\
(.11)\end{array}$ \\
\hline mover ${ }^{*}$ change firm size & $\begin{array}{c}-7.307^{* * *} \\
(.185)\end{array}$ & $\begin{array}{c}-6.885^{* * *} \\
(.149)\end{array}$ & $\begin{array}{c}-6.9^{* * *} \\
(.149)\end{array}$ & $\begin{array}{c}-7.333^{* * *} \\
(.145)\end{array}$ & $\begin{array}{c}-6.425^{* * *} \\
(.146)\end{array}$ \\
\hline change real wage (log) & & $\begin{array}{c}42.524^{* * *} \\
(.115)\end{array}$ & $\begin{array}{c}42.025^{* * *} \\
(.145)\end{array}$ & $\begin{array}{c}186.897^{* * *} \\
(1.193)\end{array}$ & $\begin{array}{c}199.405^{* * *} \\
\quad(1.224)\end{array}$ \\
\hline mover $*$ wage change & & $\begin{array}{c}-15.004^{* * *} \\
(.468)\end{array}$ & $\begin{array}{c}-15.077^{* * *} \\
(.469)\end{array}$ & $\begin{array}{c}-24.011^{* * *} \\
(.461)\end{array}$ & $\begin{array}{c}-203.241^{* * *} \\
(4.919)\end{array}$ \\
\hline init. wage & & & $\begin{array}{c}-.966^{* * *} \\
(.171)\end{array}$ & $\begin{array}{r}-.169 \\
(.167)\end{array}$ & $\begin{array}{c}-.619^{* * *} \\
(.166)\end{array}$ \\
\hline init. wage ${ }^{*} \mathrm{w}$ change & & & & $\begin{array}{c}-19.698^{* * *} \\
(.161)\end{array}$ & $\begin{array}{c}-21.44^{* * *} \\
(.165)\end{array}$ \\
\hline mover $*$ init. wage & & & & & $\begin{array}{c}4.199^{* * *} \\
(.297)\end{array}$ \\
\hline mover ${ }^{*}$ init. $\mathrm{w}^{*} \mathrm{w}$ change & & & & & $\begin{array}{c}26.156^{* * *} \\
(.7)\end{array}$ \\
\hline Const. & $\begin{array}{c}15.625^{* * *} \\
(4.761)\end{array}$ & $\begin{array}{c}4.892 \\
(3.83)\end{array}$ & $\begin{array}{c}10.758^{* * *} \\
(3.968)\end{array}$ & $\begin{array}{l}1.103 \\
(3.859)\end{array}$ & $\begin{array}{c}5.18 \\
(3.844)\end{array}$ \\
\hline Obs. & 350,020 & 350,020 & 350,020 & 350,020 & 350,020 \\
\hline$\sigma_{\mu}$ & 10.59 & 8.60 & 8.56 & 8.35 & 8.31 \\
\hline$\sigma_{\varepsilon}$ & 12.92 & 10.39 & 10.39 & 10.10 & 10.06 \\
\hline$\rho$ & 0.40 & 0.41 & 0.40 & 0.41 & 0.41 \\
\hline
\end{tabular}

Table 12: Change IN RANK, WORKER FIXED EFFECTS, MALES, High SCHOOL, FIRMS LARGER THAN 100 WORKERS.

Note: Includes controls for year, industry (16 dummies), location (1 dummy), and the origin of the capital of the firm (2 dummies). Source: Computations based on Portugal, MTSS (1991-2000). 


\begin{tabular}{|c|c|c|c|c|c|}
\hline independent variable & $(1)$ & $(2)$ & $(3)$ & $(4)$ & $(5)$ \\
\hline age & $\begin{array}{c}-.982^{* * *} \\
(.164)\end{array}$ & $\begin{array}{c}-.663^{* * *} \\
(.141)\end{array}$ & $\begin{array}{c}-.587^{* * *} \\
(.141)\end{array}$ & $\begin{array}{c}-.474^{* * *} \\
(.136)\end{array}$ & $\begin{array}{c}-.504^{* * *} \\
(.136)\end{array}$ \\
\hline age sq. / 100 & $\begin{array}{l}1.214^{* * *} \\
(.084)\end{array}$ & $\begin{array}{c}.775^{* * *} \\
(.072)\end{array}$ & $\begin{array}{c}.682^{* * *} \\
(.074)\end{array}$ & $\begin{array}{c}.536^{* * *} \\
(.071)\end{array}$ & $\begin{array}{c}.553^{* * *} \\
(.071)\end{array}$ \\
\hline tenure (previous job) & $\begin{array}{l}.021 \\
(.025)\end{array}$ & $\begin{array}{r}-.003 \\
(.022)\end{array}$ & $\begin{array}{l}-.008 \\
(.022)\end{array}$ & $\begin{array}{l}.019 \\
(.021)\end{array}$ & $\begin{array}{l}.021 \\
(.021)\end{array}$ \\
\hline tenure sq. / 100 & $\begin{array}{c}-.181^{* *} \\
(.081)\end{array}$ & $\begin{array}{c}-.049 \\
(.07)\end{array}$ & $\begin{array}{c}-.037 \\
(.07)\end{array}$ & $\begin{array}{l}-.093 \\
(.067)\end{array}$ & $\begin{array}{l}-.099 \\
(.067)\end{array}$ \\
\hline white collar & $\begin{array}{l}.001 \\
(.116)\end{array}$ & $\begin{array}{c}.268^{* * *} \\
(.1)\end{array}$ & $\begin{array}{c}.275^{* * *} \\
(.1)\end{array}$ & $\begin{array}{c}.324^{* * *} \\
(.096)\end{array}$ & $\begin{array}{c}.328^{* * *} \\
(.096)\end{array}$ \\
\hline mover & $\begin{array}{l}2.887^{* * *} \\
(.175)\end{array}$ & $\begin{array}{c}.756^{* * *} \\
(.167)\end{array}$ & $\begin{array}{c}.756^{* * *} \\
(.167)\end{array}$ & $\begin{array}{c}.424^{* * *} \\
(.161)\end{array}$ & $\begin{array}{l}-.949 \\
(2.479)\end{array}$ \\
\hline firm closure & $\begin{array}{c}-2.166^{* * *} \\
(.564)\end{array}$ & $\begin{array}{l}.048 \\
(.487)\end{array}$ & $\begin{array}{l}.071 \\
(.487)\end{array}$ & $\begin{array}{l}.164 \\
(.468)\end{array}$ & $\begin{array}{l}-.095 \\
(.469)\end{array}$ \\
\hline change in firm size (log) & $\begin{array}{l}2.466^{* * *} \\
(.131)\end{array}$ & $\begin{array}{l}1.934^{* * *} \\
(.113)\end{array}$ & $\begin{array}{c}1.94^{* * *} \\
(.113)\end{array}$ & $\begin{array}{l}1.951^{* * *} \\
(.109)\end{array}$ & $\begin{array}{l}1.945^{* * *} \\
(.108)\end{array}$ \\
\hline mover ${ }^{*}$ change firm size & $\begin{array}{c}-2.033^{* * *} \\
(.165)\end{array}$ & $\begin{array}{c}-1.675^{* * *} \\
(.141)\end{array}$ & $\begin{array}{c}-1.69^{* * *} \\
(.141)\end{array}$ & $\begin{array}{c}-1.844^{* * *} \\
(.136)\end{array}$ & $\begin{array}{c}-1.705^{* * *} \\
(.136)\end{array}$ \\
\hline change real wage (log) & & $\begin{array}{c}22.567^{* * *} \\
(.115)\end{array}$ & $\begin{array}{c}22.088^{* * *} \\
(.138)\end{array}$ & $\begin{array}{c}143.702^{* * *} \\
(1.268)\end{array}$ & $\begin{array}{c}151.666^{* * *} \\
(1.325)\end{array}$ \\
\hline mover $*$ wage change & & $\begin{array}{c}-2.7^{* * *} \\
(.385)\end{array}$ & $\begin{array}{c}-2.716^{* * *} \\
(.385)\end{array}$ & $\begin{array}{c}-7.45^{* * *} \\
(.374)\end{array}$ & $\begin{array}{c}-91.185^{* * *} \\
(4.512)\end{array}$ \\
\hline init. wage & & & $\begin{array}{c}-.967^{* * *} \\
(.156)\end{array}$ & $\begin{array}{c}.695^{* * *} \\
(.151)\end{array}$ & $\begin{array}{c}.669^{* * *} \\
(.151)\end{array}$ \\
\hline init. wage ${ }^{*} \mathrm{w}$ change & & & & $\begin{array}{c}-15.456^{* * *} \\
(.16)\end{array}$ & $\begin{array}{c}-16.479^{* * *} \\
(.168)\end{array}$ \\
\hline mover $*$ init. wage & & & & & $\begin{array}{r}.262 \\
(.319)\end{array}$ \\
\hline mover $*$ init. $\mathrm{w}^{*} \mathrm{w}$ change & & & & & $\begin{array}{c}11.112^{* * * *} \\
(.587)\end{array}$ \\
\hline Const. & $\begin{array}{c}22.616^{* * *} \\
\quad(5.304)\end{array}$ & $\begin{array}{c}14.499^{* * *} \\
(4.555)\end{array}$ & $\begin{array}{c}20.31^{* * *} \\
(4.65)\end{array}$ & $\begin{array}{l}4.927 \\
(4.479)\end{array}$ & $\begin{array}{l}5.921 \\
(4.473)\end{array}$ \\
\hline Obs. & 165,896 & 165,896 & 165,896 & 165,896 & 165,896 \\
\hline$\sigma_{\mu}$ & 8.24 & 6.94 & 6.90 & 6.76 & 6.74 \\
\hline$\sigma_{\varepsilon}$ & 8.58 & 7.36 & 7.36 & 7.09 & 7.08 \\
\hline$\rho$ & 0.48 & 0.47 & 0.48 & 0.48 & 0.48 \\
\hline
\end{tabular}

Table 13: ChANGe in RANK, WORKER FIXED EFFECTS, MALES, UNIVERSity, FIRMS LARGER THAN 100 WORKERS.

Note: Includes controls for year, industry (16 dummies), location (1 dummy), and the origin of the capital of the firm (2 dummies). Source: Computations based on Portugal, MTSS (1991-2000). 


\begin{tabular}{|c|c|c|c|c|c|}
\hline independent variable & $(1)$ & $(2)$ & $(3)$ & $(4)$ & $(5)$ \\
\hline age & $\begin{array}{c}-.414^{* * *} \\
(.124)\end{array}$ & $\begin{array}{c}.243^{* *} \\
(.101)\end{array}$ & $\begin{array}{c}.243^{* *} \\
(.101)\end{array}$ & $\begin{array}{c}-.118 \\
(.1)\end{array}$ & $\begin{array}{l}-.12 \\
(.1)\end{array}$ \\
\hline age sq. / 100 & $\begin{array}{c}.562^{* * *} \\
(.061)\end{array}$ & $\begin{array}{c}.478^{* * *} \\
(.05)\end{array}$ & $\begin{array}{c}.478^{* * *} \\
(.05)\end{array}$ & $\begin{array}{c}.328^{* * *} \\
(.049)\end{array}$ & $\begin{array}{c}.331^{* * *} \\
(.049)\end{array}$ \\
\hline tenure (previous job) & $\begin{array}{c}-.269^{* * *} \\
(.022)\end{array}$ & $\begin{array}{c}-.067^{* * *} \\
(.018)\end{array}$ & $\begin{array}{c}-.066^{* * *} \\
(.018)\end{array}$ & $\begin{array}{l}.012 \\
(.018)\end{array}$ & $\begin{array}{l}.012 \\
(.018)\end{array}$ \\
\hline tenure sq. / 100 & $\begin{array}{c}.848^{* * *} \\
(.063)\end{array}$ & $\begin{array}{c}.133^{* * *} \\
(.051)\end{array}$ & $\begin{array}{c}.128^{* *} \\
(.051)\end{array}$ & $\begin{array}{c}-.116^{* *} \\
(.051)\end{array}$ & $\begin{array}{c}-.118^{* *} \\
(.051)\end{array}$ \\
\hline white collar & $\begin{array}{l}.295^{* *} \\
(.144)\end{array}$ & $\begin{array}{l}-.221^{*} \\
(.118)\end{array}$ & $\begin{array}{l}-.214^{*} \\
(.118)\end{array}$ & $\begin{array}{l}-.121 \\
(.116)\end{array}$ & $\begin{array}{l}-.12 \\
(.116)\end{array}$ \\
\hline mover & $\begin{array}{c}-2.581^{* * *} \\
(.243)\end{array}$ & $\begin{array}{c}-4.791^{* * *} \\
\quad(.207)\end{array}$ & $\begin{array}{c}-4.798^{* * *} \\
(.207)\end{array}$ & $\begin{array}{c}-5.25^{* * *} \\
(.204)\end{array}$ & $\begin{array}{c}-14.745^{* * *} \\
(3.638)\end{array}$ \\
\hline firm closure & $\begin{array}{c}-1.292^{* *} \\
(.552)\end{array}$ & $\begin{array}{l}-.629 \\
(.452)\end{array}$ & $\begin{array}{l}-.628 \\
(.452)\end{array}$ & $\begin{array}{l}-.312 \\
(.445)\end{array}$ & $\begin{array}{l}-.464 \\
(.446)\end{array}$ \\
\hline change in firm size (log) & $\begin{array}{c}5.649^{* * *} \\
(.122)\end{array}$ & $\begin{array}{c}6.071^{* * *} \\
(.1)\end{array}$ & $\begin{array}{c}6.072^{* * *} \\
(.1)\end{array}$ & $\begin{array}{c}6.054^{* * *} \\
(.098)\end{array}$ & $\begin{array}{l}6.052^{* * *} \\
\quad(.098)\end{array}$ \\
\hline mover ${ }^{*}$ change firm size & $\begin{array}{c}-7.6^{* * *} \\
(.204)\end{array}$ & $\begin{array}{c}-9.938^{* * *} \\
(.169)\end{array}$ & $\begin{array}{c}-9.94^{* * *} \\
(.169)\end{array}$ & $\begin{array}{c}-10.153^{* * *} \\
(.166)\end{array}$ & $\begin{array}{c}-10.091^{* * *} \\
(.167)\end{array}$ \\
\hline change real wage (log) & & $\begin{array}{c}68.511^{* * *} \\
(.123)\end{array}$ & $\begin{array}{c}68.366^{* * *} \\
(.161)\end{array}$ & $\begin{array}{c}262.405^{* * *} \\
(1.327)\end{array}$ & $\begin{array}{c}262.917^{* * *} \\
(1.34)\end{array}$ \\
\hline mover $*$ wage change & & $\begin{array}{c}-4.699^{* * *} \\
(.775)\end{array}$ & $\begin{array}{c}-4.71^{* * *} \\
(.775)\end{array}$ & $\begin{array}{c}-12.806^{* * *} \\
(.764)\end{array}$ & $\begin{array}{c}-38.185^{* * *} \\
(9.591)\end{array}$ \\
\hline init. wage & & & $\begin{array}{l}-.281 \\
(.202)\end{array}$ & $\begin{array}{c}-4.345^{* * *} \\
(.201)\end{array}$ & $\begin{array}{c}-4.376^{* * *} \\
(.201)\end{array}$ \\
\hline init. wage ${ }^{*} \mathrm{w}$ change & & & & $\begin{array}{c}-29.824^{* * *} \\
(.203)\end{array}$ & $\begin{array}{c}-29.905^{* * *} \\
(.204)\end{array}$ \\
\hline mover $*$ init. wage & & & & & $\begin{array}{c}1.548^{* * *} \\
(.583)\end{array}$ \\
\hline mover ${ }^{*}$ init. $\mathrm{w}^{*} \mathrm{w}$ change & & & & & $\begin{array}{c}4.116^{* * *} \\
(1.505)\end{array}$ \\
\hline Const. & $\begin{array}{c}9.343^{* *} \\
(3.888)\end{array}$ & $\begin{array}{l}1.301 \\
(3.182)\end{array}$ & $\begin{array}{l}3.058 \\
(3.422)\end{array}$ & $\begin{array}{c}25.222^{* * *} \\
\quad(3.37)\end{array}$ & $\begin{array}{c}25.488^{* * *} \\
\quad(3.37)\end{array}$ \\
\hline Obs. & 903,342 & 903,342 & 903,342 & 903,342 & 903,342 \\
\hline$\sigma_{\mu}$ & 11.77 & 9.58 & 9.57 & 9.56 & 9.56 \\
\hline$\sigma_{\varepsilon}$ & 17.48 & 14.30 & 14.30 & 14.07 & 14.07 \\
\hline$\rho$ & 0.32 & 0.31 & 0.31 & 0.32 & 0.32 \\
\hline
\end{tabular}

Table 14: Change In RANK, WORKER FIXED EFFECTS, FEMALES, BELOW HIGH SCHOOL, FIRMS LARGER THAN 100 WORKERS.

Note: Includes controls for year, industry (16 dummies), location (1 dummy), and the origin of the capital of the firm (2 dummies). Source: Computations based on Portugal, MTSS (1991-2000). 


\begin{tabular}{|c|c|c|c|c|c|}
\hline independent variable & $(1)$ & $(2)$ & $(3)$ & $(4)$ & $(5)$ \\
\hline age & $\begin{array}{l}-.214 \\
(.247)\end{array}$ & $\begin{array}{l}-.102 \\
(.193)\end{array}$ & $\begin{array}{l}-.096 \\
(.193)\end{array}$ & $\begin{array}{l}.064 \\
(.191)\end{array}$ & $\begin{array}{l}.027 \\
(.191)\end{array}$ \\
\hline age sq. / 100 & $\begin{array}{c}.427^{* * *} \\
(.159)\end{array}$ & $\begin{array}{l}.16 \\
(.124)\end{array}$ & $\begin{array}{l}.149 \\
(.125)\end{array}$ & $\begin{array}{l}-.064 \\
(.123)\end{array}$ & $\begin{array}{l}-.012 \\
(.123)\end{array}$ \\
\hline tenure (previous job) & $\begin{array}{c}-.102^{* *} \\
(.048)\end{array}$ & $\begin{array}{l}.021 \\
(.038)\end{array}$ & $\begin{array}{l}.021 \\
(.038)\end{array}$ & $\begin{array}{l}.063^{*} \\
(.037)\end{array}$ & $\begin{array}{l}.053 \\
(.037)\end{array}$ \\
\hline tenure sq. / 100 & $\begin{array}{c}.74^{* * *} \\
(.167)\end{array}$ & $\begin{array}{c}.06 \\
(.131)\end{array}$ & $\begin{array}{l}.053 \\
(.131)\end{array}$ & $\begin{array}{c}-.098 \\
(.13)\end{array}$ & $\begin{array}{l}-.15 \\
(.129)\end{array}$ \\
\hline white collar & $\begin{array}{c}.12 \\
(.243)\end{array}$ & $\begin{array}{c}-.177 \\
(.19)\end{array}$ & $\begin{array}{c}-.174 \\
(.19)\end{array}$ & $\begin{array}{l}-.195 \\
(.188)\end{array}$ & $\begin{array}{l}-.167 \\
(.188)\end{array}$ \\
\hline mover & $\begin{array}{c}-7.085^{* * *} \\
(.345)\end{array}$ & $\begin{array}{c}-9.053^{* * *} \\
(.296)\end{array}$ & $\begin{array}{c}-9.052^{* * *} \\
(.296)\end{array}$ & $\begin{array}{c}-9.036^{* * *} \\
(.292)\end{array}$ & $\begin{array}{c}-25.838^{* * *} \\
(3.441)\end{array}$ \\
\hline firm closure & $\begin{array}{c}11.673^{* * *} \\
(.756)\end{array}$ & $\begin{array}{c}13.82^{* * *} \\
(.595)\end{array}$ & $\begin{array}{c}13.829^{* * *} \\
(.595)\end{array}$ & $\begin{array}{c}13.715^{* * *} \\
(.587)\end{array}$ & $\begin{array}{c}13.27^{* * *} \\
(.587)\end{array}$ \\
\hline change in firm size (log) & $\begin{array}{c}4.939^{* * *} \\
(.196)\end{array}$ & $\begin{array}{c}3.877^{* * *} \\
(.153)\end{array}$ & $\begin{array}{c}3.879^{* * *} \\
(.153)\end{array}$ & $\begin{array}{c}3.75^{* * *} \\
(.151)\end{array}$ & $\begin{array}{c}3.718^{* * *} \\
(.151)\end{array}$ \\
\hline mover $*$ change firm size & $\begin{array}{c}-8.81^{* * *} \\
(.27)\end{array}$ & $\begin{array}{c}-8.001^{* * *} \\
(.211)\end{array}$ & $\begin{array}{c}-8.004^{* * *} \\
(.211)\end{array}$ & $\begin{array}{c}-7.973^{* * *} \\
(.208)\end{array}$ & $\begin{array}{c}-7.771^{* * *} \\
\quad(.209)\end{array}$ \\
\hline change real wage (log) & & $\begin{array}{c}53.278^{* * *} \\
\quad(.177)\end{array}$ & $\begin{array}{c}53.125^{* * *} \\
\quad(.228)\end{array}$ & $\begin{array}{c}178.791^{* * *} \\
(1.984)\end{array}$ & $\begin{array}{c}185.134^{* * *} \\
(2.023)\end{array}$ \\
\hline mover ${ }^{*}$ wage change & & $\begin{array}{c}-17.918^{* * *} \\
(.829)\end{array}$ & $\begin{array}{c}-17.952^{* * *} \\
(.829)\end{array}$ & $\begin{array}{c}-25.128^{* * *} \\
(.826)\end{array}$ & $\begin{array}{c}-162.921^{* * *} \\
(9.977)\end{array}$ \\
\hline init. wage & & & $\begin{array}{l}-.29 \\
(.273)\end{array}$ & $\begin{array}{c}-.286 \\
(.27)\end{array}$ & $\begin{array}{c}-.478^{*} \\
(.27)\end{array}$ \\
\hline init. wage ${ }^{*} \mathrm{w}$ change & & & & $\begin{array}{c}-17.877^{* * *} \\
(.28)\end{array}$ & $\begin{array}{c}-18.795^{* * *} \\
(.286)\end{array}$ \\
\hline mover $*$ init. wage & & & & & $\begin{array}{c}2.604^{* * *} \\
(.508)\end{array}$ \\
\hline mover $*$ init. $\mathrm{w} * \mathrm{w}$ change & & & & & $\begin{array}{c}20.841^{* * *} \\
\quad(1.482)\end{array}$ \\
\hline Const. & $\begin{array}{l}4.974 \\
(6.504)\end{array}$ & $\begin{array}{l}-.609 \\
(5.093)\end{array}$ & $\begin{array}{l}1.238 \\
(5.38)\end{array}$ & $\begin{array}{l}-2.505 \\
(5.308)\end{array}$ & $\begin{array}{l}-.563 \\
(5.304)\end{array}$ \\
\hline Obs. & 209,815 & 209,815 & 209,815 & 209,815 & 209,815 \\
\hline$\sigma_{\mu}$ & 11.73 & 9.30 & 9.29 & 9.15 & 9.15 \\
\hline$\sigma_{\varepsilon}$ & 13.76 & 10.77 & 10.77 & 10.62 & 10.62 \\
\hline$\rho$ & 0.42 & 0.43 & 0.43 & 0.43 & 0.43 \\
\hline
\end{tabular}

Table 15: ChANGE In RANK, WORKER FIXED EFFECTS, FEMALES, High SCHOOL, FIRMS LARGER THAN 100 WORKERS.

Note: Includes controls for year, industry (16 dummies), location (1 dummy), and the origin of the capital of the firm (2 dummies). Source: Computations based on Portugal, MTSS (1991-2000). 


\begin{tabular}{|c|c|c|c|c|c|}
\hline independent variable & $(1)$ & $(2)$ & $(3)$ & $(4)$ & $(5)$ \\
\hline age & $\begin{array}{l}-.57^{*} \\
(.328)\end{array}$ & $\begin{array}{l}-.248 \\
(.265)\end{array}$ & $\begin{array}{l}-.097 \\
(.265)\end{array}$ & $\begin{array}{c}-.028 \\
(.26)\end{array}$ & $\begin{array}{l}-.065 \\
(.259)\end{array}$ \\
\hline age sq. / 100 & $\begin{array}{c}1.281^{* * *} \\
(.193)\end{array}$ & $\begin{array}{c}.783^{* * *} \\
(.156)\end{array}$ & $\begin{array}{c}.582^{* * *} \\
(.158)\end{array}$ & $\begin{array}{c}.374^{* *} \\
(.155)\end{array}$ & $\begin{array}{c}.442^{* * *} \\
(.154)\end{array}$ \\
\hline tenure (previous job) & $\begin{array}{l}-.048 \\
(.055)\end{array}$ & $\begin{array}{l}-.005 \\
(.044)\end{array}$ & $\begin{array}{l}-.021 \\
(.044)\end{array}$ & $\begin{array}{l}-.019 \\
(.044)\end{array}$ & $\begin{array}{r}-.018 \\
(.043)\end{array}$ \\
\hline tenure sq. / 100 & $\begin{array}{l}.129 \\
(.197)\end{array}$ & $\begin{array}{r}.079 \\
(.159)\end{array}$ & $\begin{array}{l}.119 \\
(.159)\end{array}$ & $\begin{array}{l}.107 \\
(.156)\end{array}$ & $\begin{array}{l}.073 \\
(.155)\end{array}$ \\
\hline white collar & $\begin{array}{c}-.468^{* *} \\
(.231)\end{array}$ & $\begin{array}{l}.114 \\
(.187)\end{array}$ & $\begin{array}{l}.145 \\
(.187)\end{array}$ & $\begin{array}{l}.147 \\
(.183)\end{array}$ & $\begin{array}{l}.151 \\
(.182)\end{array}$ \\
\hline mover & $\begin{array}{l}.129 \\
(.348)\end{array}$ & $\begin{array}{c}-1.399^{* * *} \\
(.326)\end{array}$ & $\begin{array}{c}-1.385^{* * *} \\
(.326)\end{array}$ & $\begin{array}{c}-1.246^{* * *} \\
(.32)\end{array}$ & $\begin{array}{c}-48.758^{* * *} \\
(4.425)\end{array}$ \\
\hline firm closure & $\begin{array}{l}1.015 \\
(.841)\end{array}$ & $\begin{array}{c}2.271^{* * *} \\
(.684)\end{array}$ & $\begin{array}{c}2.364^{* * *} \\
(.683)\end{array}$ & $\begin{array}{c}2.331^{* * *} \\
(.67)\end{array}$ & $\begin{array}{c}1.978^{* * *} \\
(.668)\end{array}$ \\
\hline change in firm size (log) & $\begin{array}{c}2.511^{* * *} \\
(.238)\end{array}$ & $\begin{array}{c}2.019^{* * *} \\
(.192)\end{array}$ & $\begin{array}{c}2.045^{* * *} \\
(.192)\end{array}$ & $\begin{array}{c}2.094^{* * *} \\
(.189)\end{array}$ & $\begin{array}{c}2.049^{* * *} \\
(.188)\end{array}$ \\
\hline mover $*$ change firm size & $\begin{array}{c}-3.713^{* * *} \\
(.304)\end{array}$ & $\begin{array}{c}-3.611^{* * *} \\
(.246)\end{array}$ & $\begin{array}{c}-3.659^{* * *} \\
(.246)\end{array}$ & $\begin{array}{c}-3.929^{* * *} \\
(.241)\end{array}$ & $\begin{array}{c}-3.247^{* * *} \\
(.243)\end{array}$ \\
\hline change real wage (log) & & $\begin{array}{c}36.871^{* * *} \\
(.209)\end{array}$ & $\begin{array}{c}35.728^{* * *} \\
(.26)\end{array}$ & $\begin{array}{c}155.35^{* * *} \\
(2.444)\end{array}$ & $\begin{array}{c}166.755^{* * *} \\
(2.526)\end{array}$ \\
\hline mover $*$ wage change & & $\begin{array}{c}-14.818^{* * *} \\
(.829)\end{array}$ & $\begin{array}{c}-14.982^{* * *} \\
(.829)\end{array}$ & $\begin{array}{c}-20.15^{* * *} \\
(.82)\end{array}$ & $\begin{array}{c}-141.522^{* * *} \\
(9.677)\end{array}$ \\
\hline init. wage & & & $\begin{array}{c}-2.232^{* * *} \\
(.303)\end{array}$ & $\begin{array}{c}-.632^{* *} \\
(.299)\end{array}$ & $\begin{array}{c}-.877^{* * *} \\
(.299)\end{array}$ \\
\hline init. wage ${ }^{*} \mathrm{w}$ change & & & & $\begin{array}{c}-15.769^{* * *} \\
(.32)\end{array}$ & $\begin{array}{c}-17.306^{* * *} \\
(.332)\end{array}$ \\
\hline mover $*$ init. wage & & & & & $\begin{array}{c}6.368^{* * *} \\
(.585)\end{array}$ \\
\hline mover $*$ init. $\mathrm{w}{ }^{*} \mathrm{w}$ change & & & & & $\begin{array}{c}17.334^{* * *} \\
(1.313)\end{array}$ \\
\hline Const. & $\begin{array}{c}10.847 \\
(9.097)\end{array}$ & $\begin{array}{c}.906 \\
(7.35)\end{array}$ & $\begin{array}{c}14.39^{*} \\
(7.572)\end{array}$ & $\begin{array}{c}1.67 \\
(7.429)\end{array}$ & $\begin{array}{c}4.052 \\
(7.4)\end{array}$ \\
\hline Obs. & 88,666 & 88,666 & 88,666 & 88,666 & 88,666 \\
\hline$\sigma_{\mu}$ & 10.95 & 8.83 & 8.59 & 8.17 & 8.16 \\
\hline$\sigma_{\varepsilon}$ & 10.69 & 8.63 & 8.63 & 8.46 & 8.43 \\
\hline$\rho$ & 0.51 & 0.51 & 0.50 & 0.48 & 0.48 \\
\hline
\end{tabular}

Table 16: ChANGe in RANK, WORKER FIXED EFFECTS, FEMALES, UNIVERSITY, FIRMS LARGER THAN 100 WORKERS.

Note: Includes controls for year, industry (16 dummies), location (1 dummy), and the origin of the capital of the firm (2 dummies). Source: Computations based on Portugal, MTSS (1991-2000). 